$\underline{\text { Article }}$

\title{
Synthesis of Analogues of 2-iodohexadecanal, a Regulator of Iodine Metabolism in the Thyroid Gland
}

\author{
Hugues Van den Bergen, Désiré Daloze, and Jean-Claude Braekman*
}

Laboratory of Bio-organic Chemistry (CP 160/07), Department of Organic Chemistry, Faculty of Sciences, University of Brussels, 50 Av.F.D.Roosevelt, 1050 Brussels, Belgium

\begin{abstract}
Com o objetivo futuro de fazer um estudo da relação estrutura-atividade, foram sintetisados vários derivados do 2-iodo-hexadecanal [1], um regulador do metabolismo de iodo na glândula tireóide, que diferem no comprimento da cadeia, natureza do substituinte e grupo funcional terminal.

With the object of performing a structure-activity relationship study, we have synthesized several analogues of 2-iodohexadecanal [1], a regulator of iodine metabolism in the thyroid gland, differing by the chain length, the nature of the substituent, and/or the terminal functional group.
\end{abstract}

Keywords: $\alpha$-halogenocarbonyl compounds, 2-iodohexadecanal

\section{Introduction}

As a part of a program dealing with the regulation of the thyroid gland metabolism by iodide, 2-iodohexadecanal [1] has been identified as a major iodolipid ${ }^{1}$. It is formed upon addition of iodine to the vinyl diethylether group of plasmalogens followed by hydrolysis ${ }^{1,2}$. The investigation of the biological activities of synthetic $( \pm)-\mathbf{1}$ revealed its ability to inhibit both $\mathrm{H}_{2} \mathrm{O}_{2}$ production in cultured dog thyroid cells $^{3}$ and the human thyroid adenylyl cyclase ${ }^{4}$. (2S)-1 and (2R)-1 exhibit identical biological activities, thus suggesting the lack of stereoselectivity in their interaction with the biological receptors 5 .

Prompted by these interesting findings, we decided to investigate the structural parameters of $\mathbf{1}$ required for observation of biological activities. Thus, a series of analogues of $\mathbf{1}$ differing by the chain length (n), the nature of the substituent $(\mathbf{X})$ and that of the terminal function $(\mathbf{Y})$

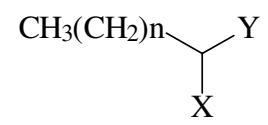

Figure 1. $X=I$ and $Y=C H O: 1 n=13 ; 2 n=5 ; 3 n=9 ; 4 n=15 ; 5 n=$ 17. $\mathrm{Y}=\mathrm{CHO}$ and $\mathrm{n}=13: 6 \mathrm{X}=\mathrm{Br} ; 7 \mathrm{X}=\mathrm{Cl} ; 8 \mathrm{X}=\mathrm{F} ; 9 \mathrm{X}=\mathrm{H} ; 10 \mathrm{X}=$ OMs. $\mathrm{Y}=\mathrm{COCH}_{3}$ and $\mathrm{n}=5: 11 \mathrm{X}=\mathrm{I} ; 12 \mathrm{X}=\mathrm{Br} ; 13 \mathrm{X}=\mathrm{Cl} ; 14 \mathrm{X}=\mathrm{F}$; $15 \mathrm{X}=\mathrm{H} ; 16 \mathrm{X}=\mathrm{OTs}$. $\mathrm{X}=\mathrm{I}$ and $\mathrm{n}=13: 17 \mathrm{Y}=\mathrm{COCH}_{3} ; 18 \mathrm{Y}=\mathrm{COOH}$; $19 \mathrm{Y}=\mathrm{COOCH}_{3} ; 20 \mathrm{Y}=\mathrm{CH}_{2} \mathrm{OH} ; 21 \mathrm{Y}=\mathrm{CH}\left(\mathrm{OCH}_{3}\right)_{2} ; 22 \mathrm{Y}=\mathrm{CONH}_{2}$; $23 \mathrm{Y}=\mathrm{CN}$ have been synthesized. The syntheses of these analogues, all of them new compounds, are presented in this paper.

\section{Results and Discussion}

Syntheses of 2-halogenoaldehydes 1-8, 2-iodohexadecanoic acid [18], methyl 2-iodohexadecanoate [19] and 2-iodohexadecanamide [22]

2-Iodoaldehydes 1-5 were synthesized by direct iodination of the corresponding long chain aldehydes using the mixture $\mathrm{HgCl}_{2} / \mathrm{I}_{2}$ (yield: $\left.50-60 \%\right)^{6}$. In our hands, this method was superior to the alternative one passing through substitution of the bromine of 2-bromoaldehydes by iodine ( $\mathrm{NaI} / \mathrm{CH}_{3} \mathrm{CN}$; yield $86 \%$ ), as bromination of the $n$-aldehydes was only achieved with rather low yields. For example, 2-bromohexadecanal [6] was synthesized by direct bromination of $n$-hexadecanal with $t$-BuBr/DMSO in a $41 \%$ yield $^{7}$.

$n$-Octanal and $n$-dodecanal are commercially available. $n$-Hexadecanal, $n$-octadecanal and $n$-eicosanal were synthesized by PCC oxidation of the corresponding alcohols in an $80-90 \%$ yield $^{8}$.

2-Chlorohexadecanal [7] was synthesized in two steps by chlorination of $n$-hexadecanal dimethylacetal [24], using the mixture $\mathrm{MnCl}_{2} / \mathrm{MnO}_{2} / \mathrm{TMSCl}^{9}$ to afford 25 in $67 \%$ yield, followed by acid hydrolysis of 25 with $\mathrm{CF}_{3} \mathrm{COOH} / \mathrm{H}_{2} \mathrm{O} / \mathrm{CH}_{2} \mathrm{Cl}_{2}$ (yield $71 \%$ ). We have found these $\alpha$-chloroacetal hydrolysis conditions to be an efficient al- 
ternative to those described by Boni et al. $\left(\mathrm{AcOH} / \mathrm{HCl}^{10}\right.$ or $\mathrm{Ac}_{2} \mathrm{O} / \mathrm{AcCl} / \mathrm{AcONa} 3 \mathrm{H}_{2} \mathrm{O}^{11}$ ). Moreover, neither direct chlorination of $n$-hexadecanal [9] with $\mathrm{SO}_{2} \mathrm{Cl}_{2}{ }^{12}$, or $n$ hexadecanal trimethylsilylenolether with $\mathrm{Cl}_{2}{ }^{13}$ led to the formation of 2-chlorohexadecanal [7], probably because $n$-hexadecanal or 2-chlorohexadecanal polymerized under the reaction conditions.

Several methods have been described in the literature for the preparation of 2-fluoroaldehydes but they present significant drawbacks, such as poor yields or the need of fluorine gas $^{14-18}$. Our approach to the synthesis of 2fluoroaldehydes avoids these drawbacks. Our synthesis of 2-fluorohexadecanal [8] was based on a described synthesis of 2-fluorooctadecanoic acid ${ }^{19}$. Hexadecanoic acid [26] was brominated using the mixture $\mathrm{P} / \mathrm{Br}_{2}$, esterified with methanol (yield: 67\%), and the bromine of the resulting bromoester [27] exchanged by fluorine [AgF/ $\mathrm{CH}_{3} \mathrm{CN} /$ $\mathrm{H}_{2} \mathrm{O}$; yield: 50\%)] to afford methyl 2-fluorohexadecanoate [29] (Scheme 2). Several attempts to reduce the ester function of 29 into an aldehyde using DIBAH under different reaction conditions $\left(-78{ }^{\circ} \mathrm{C}\right.$; in hexane, diethylether, $\mathrm{CH}_{2} \mathrm{Cl}_{2}$ or toluene) always led to a mixture of the reactant and 2-fluorohexadecanol. Therefore, $\mathbf{2 9}$ was first reduced to 2-fluorohexadecanol in an $83 \%$ yield using $\mathrm{LiAlH}_{4}$, followed by Swern oxidation ${ }^{20}$ which cleanly afforded 2-fluorohexadecanal [8] in a 90\% yield.

Methyl 2-iodohexadecanoate [19] was synthesized following two different procedures. 2-Iodohexadecanoic acid [18] was first prepared by direct iodination of hexadecanoic acid [26] using the mixture $\mathrm{ClSO}_{3} \mathrm{H}_{/} / \mathrm{I}_{2}{ }^{21}$. Addition of methanol to the reaction mixture afforded 19 in a $38 \%$ yield after purification by column chromatography on silica gel $^{21}$. Alternatively, compound 19 was prepared by substitution of the bromine of methyl 2-bromohexadecanoate [27] using $\mathrm{NaI}$ in $\mathrm{CH}_{3} \mathrm{CN}$ (yield: 93\%).

2-Iodohexadecanamide [22] was prepared by aminolysis of 27 with gaseous $\mathrm{NH}_{3}$ in $\mathrm{MeOH}-\mathrm{CHCl}_{3}{ }^{22}$ (yield: $55 \%$ ), followed by substitution of the bromine by iodine which gave 2-iodohexadecanamide [22] in a $92 \%$ yield.
Synthesis of 2-mesyloxyhexadecanal [10]

The preparation of 2-mesyloxy- ${ }^{23}$ and 2-tosyloxyketones $^{24}$ is already described but up to now, no method was available for the preparation of 2-mesyloxy- and 2-tosyloxyaldehydes. Attempts to prepare 2-tosyloxyhexadecanal by direct reaction of $n$-hexadecanal with $\mathrm{HTIB}^{25}$ only led to complex reaction mixtures. In contrast, the attempted reduction of 2-mesyloxyhexadecanenitrile with DIBAH led to the recovery of the starting material. We also failed to obtain 2-mesyloxyhexadecanal [10] by hydrolysis of the S,S-dioxydedithioketal ${ }^{26}$ or the dimethylketal of 2-mesyloxyhexadecanal ${ }^{27}$ probably due to the strong inductive effect of the mesyloxy group. Finally, $\mathbf{1 0}$ was synthesized starting from 1-hexadecene [30]. Dihydroxylation of 30 into 31 with $\mathrm{OsO}_{4}{ }^{28}$ followed by selective protection of the primary hydroxyl group of $\mathbf{3 1}$ with $\mathrm{TBDMSCl}^{29}$, mesylation of the secondary hydroxyl group of 32 with $\mathrm{MsCl}^{30}$ and deprotection of the primary hydroxyl group of $\mathbf{3 3}$ with TFA $^{31}$ led to 2-mesyloxyhexadecanol [34]. Swern oxidation $^{20}$ of 34 gave 2-mesyloxyhexadecanal [10] which proved to be a relatively unstable compound.

Synthesis of 3-halogeno-2-ketones 11-14, and 17 and of

3-tosyloxy-2-nonanone [16]

3-Bromo-2-nonanone [12] was synthesized regiospecifically by direct bromination of 2-nonanone [15] with the system TMSBr/DMSO ${ }^{32}$.

3-Iodo-2-nonanone [11] was cleanly synthesized in a $77 \%$ yield by substitution of the bromine of $\mathbf{1 2}$ by $\mathrm{NaI}$ in $\mathrm{CH}_{3} \mathrm{CN}$. In contrast with literature claims ${ }^{6}$, direct iodination of 2-nonanone [15] with $\mathrm{HgCl}_{2}$ and $\mathrm{I}_{2}$ was not regioselective and gave a mixture of 3-iodo-2-nonanone [11] and 1-iodo-2-nonanone (82:18), which have the same $\mathrm{R}_{\mathrm{f}}$ on TLC in different eluent systems, together with small amounts of 1,3-diiodo-2-nonanone. The same problem of regioselectivity was encountered in the direct iodination of 2-heptadecanone (see below). Thus, the first method is superior to the second one because the bromination reaction is regiospecific.

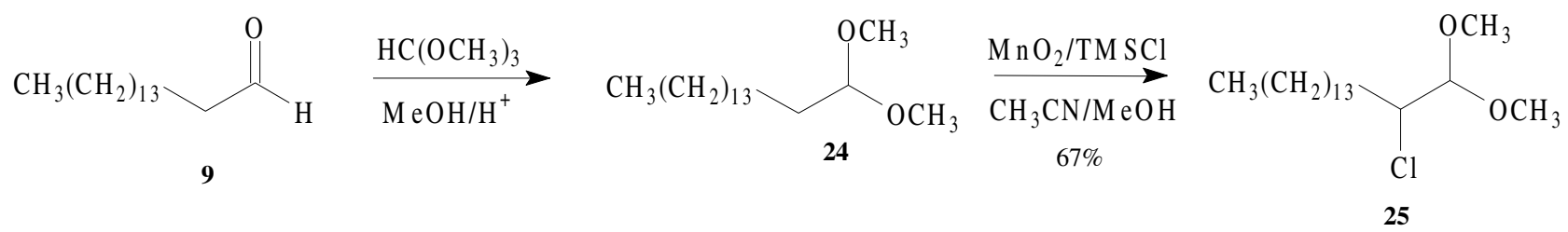<smiles>CCCCCC(=O)C(Cl)C(=O)OC(=O)C(F)(F)F</smiles>

Scheme 1. Synthesis of 2-chlorohexadecanal [7]. 


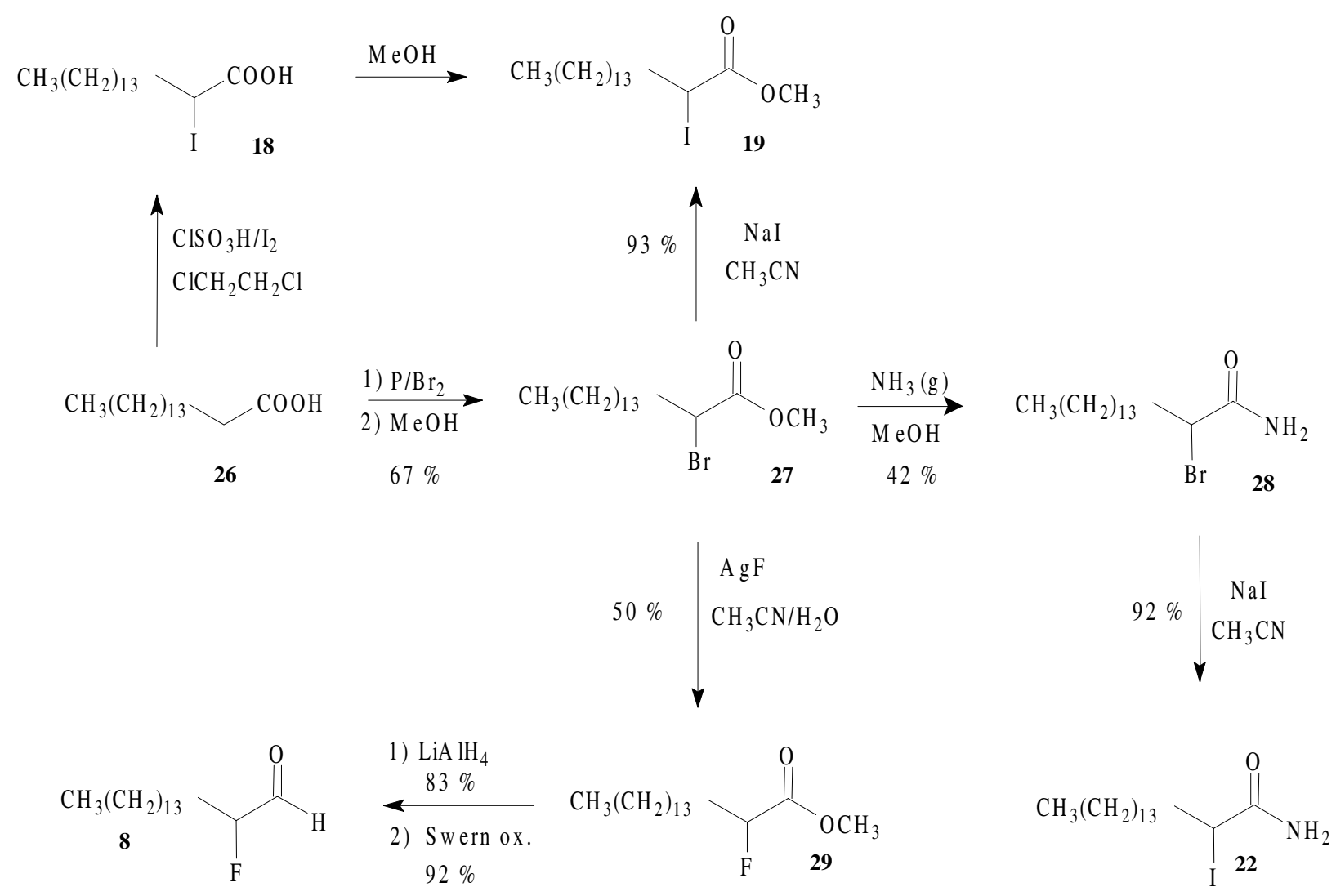

Scheme 2. Synthesis of 2-fluorohexadecanal [8], methyl 2-iodohexadecanoate [19] and 2-iodohexadecanamide [22].

$$
\mathrm{CH}_{3}\left(\mathrm{CH}_{2}\right)_{13} \mathrm{CH}=\mathrm{CH}_{2} \underset{\text { acetone }}{\stackrel{\mathrm{OsO} \mathrm{O}_{4} / \mathrm{NMO}}{\longrightarrow}}
$$

30

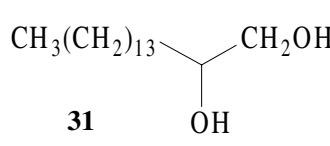

$31 \quad \mathrm{OH}$

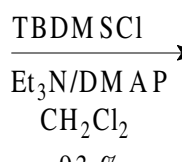

$93 \%$<smiles>CCCCCC(O)CO[Mg]</smiles>
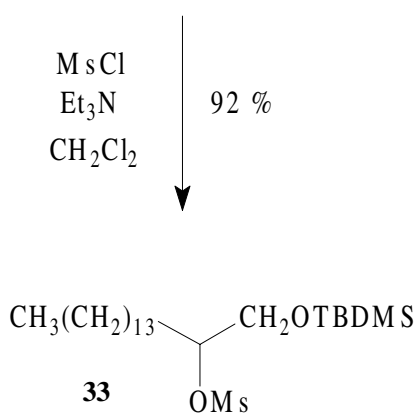

Scheme 3. Synthesis of 2-mesyloxyhexadecanal [10].

3-Chloro-2-nonanone [13] was prepared in a 92\% yield by direct chlorination of 2-nonanone [15] with $\mathrm{MnO}_{2} / \mathrm{TMSCl}$ in $\mathrm{AcOH}^{33}$. Another chlorinating system, TMSCl/DMSO in acetonitrile, is described for the introduction of a chlorine atom into the more substituted position of a ketone ${ }^{34}$. In our hands, the use of these conditions only led to 3-methylthio-2-nonanone in a $66 \%$ yield.
3-Fluoro-2-nonanone [14] was obtained by substitution of the bromine atom of 3-bromo-2-nonanone [12] with $\mathrm{AgF}^{19}$.

3-Tosyloxy-2-nonanone [16] was synthesized by direct oxidation of 2-nonanone [15] by $\mathrm{HTIB}^{25}$ which gave a mixture of 3-tosyloxy-2-nonanone [16] (yield: 30\%) and 1-tosyloxy-2-nonanone (yield: 15\%). The two compounds could be easily separated by flash chromatography. 
3-Iodo-2-heptadecanone [17] was synthesized starting from hexadecan-1-ol. Oxidation of hexadecan-1-ol by $\mathrm{PCC}^{8}$, followed by addition of methylmagnesiumbromide, hydrolysis and PCC oxidation of the resulting 2-heptadecanol [35] gave 2-heptadecanone [36]. Iodination of the latter with $\mathrm{HgCl}_{2} / \mathrm{I}_{2}{ }^{6}$ at rt. gave a 77:23 mixture of 3-iodo2-heptadecanone [17] and 1-iodo-2-heptadecanone [33] (yield: 53\%). A higher regioselectivity could be obtained at reflux $(95: 5 ; 48 \%)$. The two regioisomers could be separated by reversed phase HPLC.

Synthesis of 2-iodohexadecanol [20] and 2-iodooctanol [38]

2-Iodohexadecanol [20] and 2-iodooctanol [38] were prepared respectively by reduction of 2-iodohexadecanal [1] and 2-iodooctanal [2] by $\mathrm{NaBH}_{4}(\text { Scheme } 6)^{5}$.

Synthesis of 2-iodohexadecanenitrile [23]

2-Iodohexadecanenitrile [23] was prepared in several steps from pentadecan-1-ol [39]. The latter was first oxidized into $n$-pentadecanal [40] by PCC (yield $83 \%)^{8}$. Treatment of 40 with TMSCN and $\mathrm{ZnI}_{2}{ }^{35-38}$ afforded trimethylsilylcyanohydrin 41, which was deprotected with citric acid into 42 (yield for the two steps: 55\%). This compound was also obtained in approximately the same yield by column chromatography of crude $\mathbf{4 1}$ on silica gel. These moderate yields can be explained by partial polymerisation of $n$-pentadecanal [40] under the reaction conditions used for the cyanohydrin formation. Mesylation of cyanohydrin 42 with $\mathrm{ClSO}_{2} \mathrm{CH}_{3}$ afforded 2-mesyloxyhexadecanenitrile [43] in a $100 \%$ yield $^{30}$. Finally, 2-iodohexadecanenitrile was obtained in a $57 \%$ yield by substitution of the mesyloxy group of $\mathbf{4 3}$ by iodide.

The testing of these analogues on the $\mathrm{H}_{2} \mathrm{O}_{2}$ production and on the thyroid gland adenylyl cyclase has been performed and the results have been published elsewhere ${ }^{3,4}$.

Scheme 6. Synthesis of 2-iodohexadecanol [20] and 2-iodooctanol [38].<smiles>CCCCCC(C)=O</smiles>

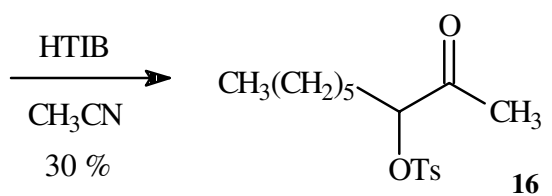
13 $92 \%$ \begin{tabular}{l|r}
$\mathrm{TMSBr} / \mathrm{DMSO}$ \\
$\mathrm{CH}_{3} \mathrm{CN}$
\end{tabular} \mid $\begin{array}{r}\mathbf{1 5} \\
\downarrow\end{array}$<smiles>CCCCC(I)C(C)=O</smiles><smiles>CCCCCC(Br)C(C)=O</smiles><smiles>CCCCOc1ccccc1</smiles><smiles>CCCCCC(F)C(C)=O</smiles>

Scheme 4. Synthesis of 3-halogeno-2-ketones 11-14, and of 3-tosyloxy-2-nonanone [16].

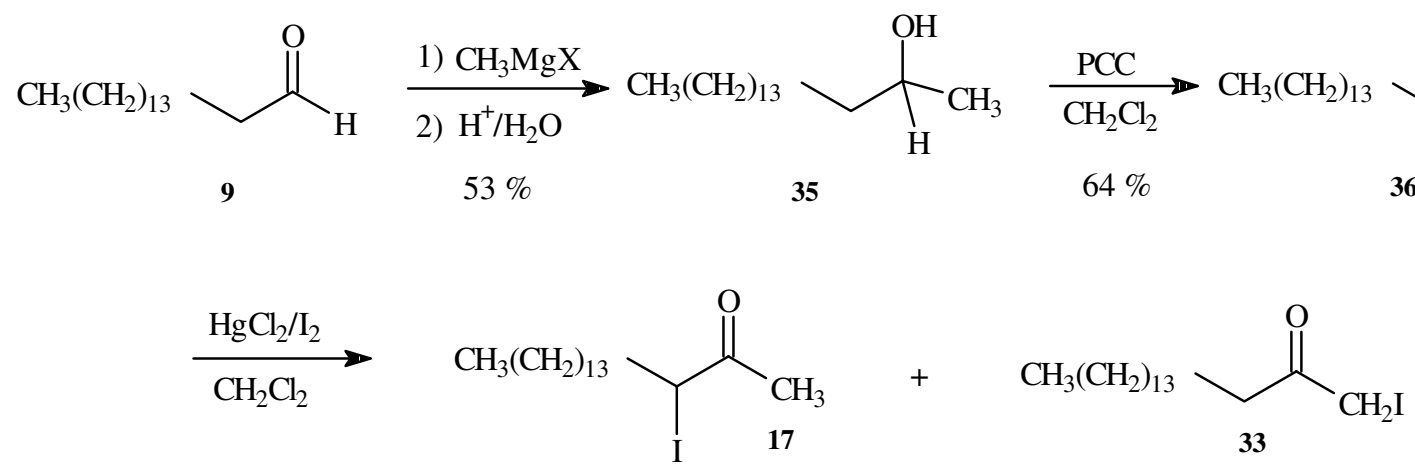

Scheme 5. Synthesis of 3-iodo-2-heptadecanone [17]. 


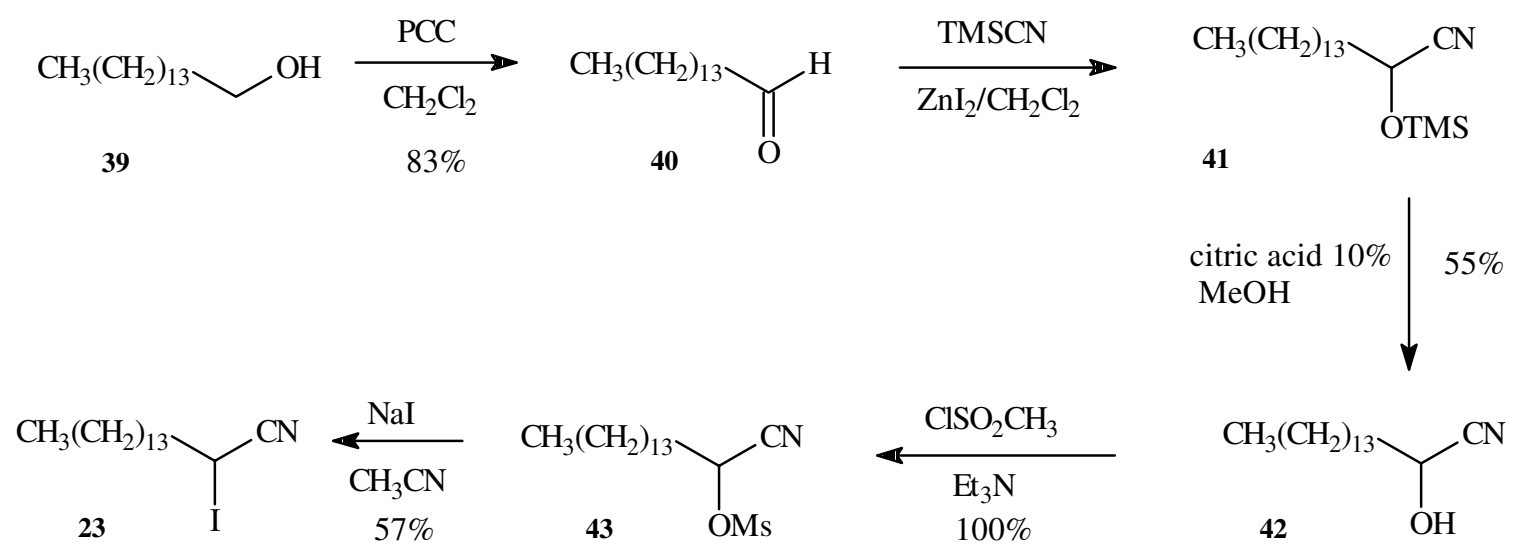

Scheme 7. Synthesis of 2-iodohexadecanamide [23].

\section{Experimental}

${ }^{1} \mathrm{H}-\mathrm{NMR}$ spectra were recorded on a BRUKER WM 250 spectrometer and are reported in ppm from internal TMS on the $\delta$ scale $\left(\mathrm{CDCl}_{3}\right)$. Data are reported as follows: chemical shift [multiplicity (s: singlet; bs: broad singlet; $\mathrm{d}$ : doublet; bd: broad doublet; t: triplet; m: multiplet; $\mathrm{dm}$ : double multiplet), coupling constant in Hertz, integration]. Infrared spectra were taken with Bruker IFS 25 instrument as a film on a $\mathrm{NaCl}$ disk unless otherwise stated. EIMS were recorded on a VG Micromass 7070 or Autospec spectrometer. Peak intensities are expressed as \% relative to the base peak. Thin layer chromatography analyses were performed on $0.25 \mathrm{~mm}$ POLYGRAM silica gel SIL G/UV $\mathrm{U}_{254}$ precoated plates (MACHEREY-NAGEL). Column chromatographies were performed over silica gel (MERCK 60 0.04-0.063 mm), using the flash technique. All reactions were run under nitrogen atmosphere. During work-up, organic solutions were dried over $\mathrm{MgSO}_{4}$.

$n$-Pentadecanal, $n$-hexadecanal [9], $n$-octadecanal and $n$-eicosanal were prepared by PCC oxidation of the corresponding alcohols. As an example, the procedure for the preparation of $n$-hexadecanal is given here.

$n$-Hexadecanal [9]. $5.33 \mathrm{~g}$ of PCC (24.7 mmol; 1.5 eq.) were suspended in $30 \mathrm{~mL}$ of dry $\mathrm{CH}_{2} \mathrm{Cl}_{2} ; 4.00 \mathrm{~g}$ of hexadecan-1-ol (16.4 mmol; 1.0 eq.) dissolved in $16 \mathrm{~mL}$ of dry $\mathrm{CH}_{2} \mathrm{Cl}_{2}$ were added at once and the reaction mixture was stirred at rt. for $1.5 \mathrm{~h}$ after which $30 \mathrm{~mL}$ of dry diethylether was added. The reaction mixture was filtered on a filter paper and the black precipitate washed with dry diethylether $(3 \times 10 \mathrm{~mL})$. Evaporation of the combined extracts in vacuo and filtration of the residue on Florisil (elution with hexane/diethylether 8:2) afforded $3.21 \mathrm{~g}$ of $n$-hexadecanal $(81 \%)$ as a white solid after evaporation of the solvent. M.p.: $30-31{ }^{\circ} \mathrm{C}$. IR: 2954, 2923, 2853, 1712, 1728, 1465, $1456 \mathrm{~cm}^{-1}$. EIMS: $\mathrm{C}_{16} \mathrm{H}_{32} \mathrm{O}(\mathrm{M}=240) ; \mathrm{m} / \mathrm{z}$ : $240\left(\mathrm{M}^{+\bullet}, 0.8\right), 222$ (0.8); $196(1.6) ; 44$ (23). ${ }^{1} \mathrm{H}-\mathrm{NMR}: 9.76$ (t, $1.9 \mathrm{~Hz}, 1 \mathrm{H}) ; 2.41$ (dt, $1.9 \mathrm{~Hz}, 7.3 \mathrm{~Hz}, 2 \mathrm{H}) ; 1.63$ (m, 2 $\mathrm{H}) ; 1.26$ (m, $24 \mathrm{H}) ; 0.88$ (m, $3 \mathrm{H})$.
n-Pentadecanal. M.p.: 55-59 ${ }^{\circ} \mathrm{C}$. IR: 2956, 2918, 2850 , 1704, $1466 \mathrm{~cm}^{-1}$. EIMS: $\mathrm{C}_{15} \mathrm{H}_{30} \mathrm{O}(\mathrm{M}=226) ; \mathrm{m} / \mathrm{z}=226$ $\left(\mathrm{M}^{+\bullet},>0\right), 225(50), 183(58), 182(83), 44(100) .{ }^{1} \mathrm{H}-$ NMR: $9.76(\mathrm{t}, 1.9 \mathrm{~Hz}, 1 \mathrm{H}) ; 2.41(\mathrm{dd}, 7.3 \mathrm{~Hz}, 1.9 \mathrm{~Hz}, 2 \mathrm{H})$; 1.57-1.72 (m, $2 \mathrm{H}) ; 1.26(\mathrm{~m}, 22 \mathrm{H}), 0.88(\mathrm{~m}, 3 \mathrm{H})$.

$n$-Octadecanal. M.p.: $41-42{ }^{\circ} \mathrm{C}$. IR: 2953, 2914, 2849 , $2746,1711,1470 \mathrm{~cm}^{-1}$. EIMS: $\mathrm{C}_{18} \mathrm{H}_{36} \mathrm{O}(\mathrm{M}=268) ; \mathrm{m} / \mathrm{z}=$ $268\left(\mathrm{M}^{+\bullet}\right), 250(21), 224(10), 85(48), 71(84), 57$ (99), 44 (50), 43 (100), 29 (67). ${ }^{1} \mathrm{H}-\mathrm{NMR}: 9.76$ (t, $\left.1.9 \mathrm{~Hz}, 1 \mathrm{H}\right) ; 2.41$ (td, $7.3 \mathrm{~Hz}, 1.9 \mathrm{~Hz}, 2 \mathrm{H}) ; 1.63$ (m, $2 \mathrm{H}) ; 1.26(\mathrm{~m}, 28 \mathrm{H})$; $0.88(\mathrm{~m}, 3 \mathrm{H})$.

$n$-Eicosanal. IR: 2915, 2848, 1711, $1471 \mathrm{~cm}^{-1}$; in $\mathrm{CCl}_{4}$ : 2932, 2854; 2714; 1729; $1468 \mathrm{~cm}^{-1}$. EIMS: $\mathrm{C}_{20} \mathrm{H}_{40} \mathrm{O}(\mathrm{M}=$ 296); $\mathrm{m} / \mathrm{z}=296\left(\mathrm{M}^{+\bullet}, 1\right) ; 278$ (2); 252 (3); 44 (18). ${ }^{1} \mathrm{H}$-NMR: 9.76 (t, $\left.1.9 \mathrm{~Hz}, 1 \mathrm{H}\right) ; 2.41$ (dt, $7.3 \mathrm{~Hz}, 1.9 \mathrm{~Hz}, 2$ $\mathrm{H}) ; 1.66-1.57(\mathrm{~m}, 2 \mathrm{H}) ; 1.26(\mathrm{~m}, 32 \mathrm{H}) ; 0.88(\mathrm{~m}, 3 \mathrm{H})$.

2-Iodooctanal [2], 2-iodododecanal [3], 2-iodohexadecanal [1], 2-iodooctadecanal [4], 2-iodoeicosanal [5] were prepared by direct iodination of the corresponding aldehydes using $\mathrm{HgCl}_{2} / \mathrm{I}_{2}$. As an example, the procedure for the preparation of 2-iodohexadecanal is given here.

2-Iodohexadecanal [1]. To $250 \mathrm{mg}(1.04 \mathrm{mmol})$ of $n$-hexadecanal in $2 \mathrm{~mL}$ of $\mathrm{CH}_{2} \mathrm{Cl}_{2}$ were added $0.141 \mathrm{~g}$ ( $0.520 \mathrm{mmol} ; 0.5$ eq.) of $\mathrm{HgCl}_{2}$ and $264 \mathrm{mg}$ (1.04 mmol; 1 eq.) of iodine. The heterogeneous reaction mixture was stirred vigorously at $\mathrm{rt}$. for $2 \mathrm{~h}$ after which the solution was filtered and the filtrate washed successively with an aqueous $0.1 \mathrm{~N}$ sodium thiosulfate solution (until discoloration) and an aqueous saturated KI solution. The organic phase was dried, evaporated in vacuo and the resulting residue submitted to flash chromatography on silica gel (hexane/diethylether 8:2) affording $212 \mathrm{mg}$ of 2-iodohexadecanal (56\%) as an oil. IR: 2953, 2923, 2852, 2710, 1719, 1466 $\mathrm{cm}^{-1}$. EIMS: $\mathrm{C}_{16} \mathrm{H}_{31} \mathrm{OI}(\mathrm{M}=366) ; \mathrm{m} / \mathrm{z} 366\left(\mathrm{M}^{+\bullet}, 0.4\right), 239$ (19); 221 (12); 170 (14); 43 (100). ${ }^{1}$ H-NMR: 9.26 (d, 3.2 $\mathrm{Hz}, 1 \mathrm{H}) ; 4.45(\mathrm{dt}, 7.3 \mathrm{~Hz}, 3.2 \mathrm{~Hz}, 1 \mathrm{H}), 1.96-1.91(\mathrm{~m}, 2 \mathrm{H})$; $1.26(\mathrm{~m}, 24 \mathrm{H}) ; 0.88$ (m, $3 \mathrm{H})$.

2-Iodooctanal [2]. Oil. IR: 2956, 2927, 2857, 2718, 1717, $1466 \mathrm{~cm}^{-1}$. EIMS: $\mathrm{C}_{8} \mathrm{H}_{15} \mathrm{OI}(\mathrm{M}=254) ; \mathrm{m} / \mathrm{z}=254$ 
$\left(\mathrm{M}^{+\bullet}, 2\right) ; 170$ (85); 127 (100); 109 (100); 84 (21). ${ }^{1} \mathrm{H}-\mathrm{NMR}:$ $9.26(\mathrm{~d}, 3.2 \mathrm{~Hz}, 1 \mathrm{H}) ; 4.45(\mathrm{td}, 7.3 \mathrm{~Hz}, 3.2 \mathrm{~Hz}, 1 \mathrm{H})$; 2.04-1.84 (m, 2 H); 1.56-1.23 (m, 8 H); 0.88 (m, 3 H).

2-Iodododecanal [3]. Oil. IR: 2954, 2924, 2854, 2722 , 1721, $1465 \mathrm{~cm}^{-1}$. EIMS: $\mathrm{C}_{12} \mathrm{H}_{23} \mathrm{OI}(\mathrm{M}=310) ; \mathrm{m} / \mathrm{z}=310$ $\left(\mathrm{M}^{+\bullet}, 0.8\right) ; 183$ (100); 170 (100); 165 (69);140 (32). ${ }^{1} \mathrm{H}-$ NMR: 9.26 (d, $3.2 \mathrm{~Hz}, 1 \mathrm{H})$; 4.45 (dt, $7.3 \mathrm{~Hz}, 3.2 \mathrm{~Hz}, 1 \mathrm{H})$; 2.00-1.90 (m, $2 \mathrm{H})$; 1.49-1.26 (m, $16 \mathrm{H})$; 0.88(m, $3 \mathrm{H})$.

2-Iodooctadecanal [4]. M.p.: 42-44 ${ }^{\circ} \mathrm{C}$. IR: 2923, 2853, 2719, 1722, $1464 \mathrm{~cm}^{-1}$. EIMS: $\mathrm{C}_{18} \mathrm{H}_{35} \mathrm{OI}(\mathrm{M}=394)$; $\mathrm{m} / \mathrm{z}=394\left(\mathrm{M}^{+\bullet}, 1.5\right), 267$ (99), 249 (99), 224 (21), 170 (100), 141 (16), 127 (25), 113 (43), 99 (96), 85 (100), 71 (100), 57 (100), 43 (100), 29 (100). ${ }^{1} \mathrm{H}-\mathrm{NMR}: 9.25$ (d, 3.2 $\mathrm{Hz}, 1 \mathrm{H}) ; 4.45$ (t, $7.3 \mathrm{~Hz}, 3.2 \mathrm{~Hz}, 1 \mathrm{H}) ; 1.94$ (m, $2 \mathrm{H}) ; 1.26$ (m, $28 \mathrm{H}) ; 0.88$ (m, $3 \mathrm{H})$.

2-Iodoeicosanal [5]. IR: 2953, 2918, 2850, 2725, 1716, $1471 \mathrm{~cm}^{-1}$. EIMS: $\mathrm{C}_{20} \mathrm{H}_{39} \mathrm{OI}(\mathrm{M}=422) ; \mathrm{m} / \mathrm{z}=422\left(\mathrm{M}^{+\bullet}\right.$, 5); 421 (10); 295 (100); 277 (100); 252 (52); 170 (100). ${ }^{1} \mathrm{H}-\mathrm{NMR}: 9.25$ (d, 3.2 Hz, 1H); 4.45 (dt, 7.3 Hz, 3.2 Hz, 1 H); 2.00-1.89 (m, 2 H); 1.49-1.26 (m, 32 H); 0.88 (m, 3 H).

2-Bromohexadecanal [6]. A mixture of $336 \mathrm{mg}$ (140 mmol, 1 eq.) of $n$-hexadecanal, $200 \mu \mathrm{L}(218 \mathrm{mg}, 240 \mathrm{mmol}$, 1.7 eq.) of DMSO and $630 \mu \mathrm{L} t$-butyl bromide $(766 \mathrm{mg}$, $560 \mathrm{mmol}, 4$ eq.) was stirred at $60-65{ }^{\circ} \mathrm{C}$ for $6 \mathrm{~h}$. The reaction mixture was poured into water and extracted with diethylether. The organic phase was dried, evaporated in vacuo and the resulting residue was chromatographed on Florisil (toluene/hexane 5:5) to afford $175 \mathrm{mg}(0.548$ mmol) of 2-bromohexadecanal [6] (41\%) as an oil. IR: 2923, 2853, 2714, 1732, 1467, $1456 \mathrm{~cm}^{-1}$. EIMS: $\mathrm{C}_{16} \mathrm{H}_{31} \mathrm{OBr}(\mathrm{M}=318) ; \mathrm{m} / \mathrm{z}=318\left(\mathrm{M}^{+\bullet}, 4\right) ; 239$ (9); 221 (19); 124 (41); 57 (100). ${ }^{1} \mathrm{H}-\mathrm{NMR}: 9.42$ (d, $\left.3.2 \mathrm{~Hz}, 1 \mathrm{H}\right)$; 4.21 (m, $1 \mathrm{H}) ; 1.2-2.4(\mathrm{~m}, 26 \mathrm{H}) ; 1.26$ (m, $3 \mathrm{H})$.

$n$-Hexadecanal methyl acetal [24]. To $100 \mathrm{mg}(0.416$ mmol; 1 eq.) of $n$-hexadecanal and $45.5 \mathrm{~L}$ ( $0.416 \mathrm{mmol} ; 1$ eq.) of methylorthoformate dry methanol $(13 \mathrm{~mL})$ were added $8 \mathrm{mg}$ ( $0.0416 \mathrm{mmol} ; 0.1$ eq.) of $p$-toluenesulfonic acid. The reaction mixture was stirred at reflux for $2 \mathrm{~h}$ after which it was diluted with pentane $(10 \mathrm{~mL})$, washed with an aqueous $\mathrm{NaOH}$ solution $(0.5 \% ; 10 \mathrm{~mL})$ and the aqueous phase extracted with pentane $(3 \times 10 \mathrm{~mL})$. The combined organic phases were dried, evaporated in vacuo and the resulting residue was flash chromatographed on silica gel (hexane/AcOEt 95:5) to afford $95.9 \mathrm{mg}(80 \%) n$-hexadecanal methyl acetal [24] as an oil. IR: 2924, 2854, 1466, 1192, 1124, 1074, $1056 \mathrm{~cm}^{-1}$. EIMS: $\mathrm{C}_{18} \mathrm{H}_{38} \mathrm{O}_{2}(\mathrm{M}=286) ; \mathrm{m} / \mathrm{z}=$ $286\left(\mathrm{M}^{+\bullet}, 7\right), 285$ (22), 255 (63), 75 (100). ${ }^{1} \mathrm{H}-\mathrm{NMR}: 4.35$ (t, $5.7 \mathrm{~Hz}, 1 \mathrm{H}) ; 3.31(\mathrm{~s}, 6 \mathrm{H}) ; 1.57(\mathrm{~m}, 2 \mathrm{H}) ; 1.25$ (m, 26 $\mathrm{H}) ; 0.88$ (m; $3 \mathrm{H})$.

2-Chlorohexadecanal methylacetal [25]. $237 \mathrm{mg}$ (0.829 mmol, 1 eq.) of $n$-hexadecanal methyl acetal and $52.1 \mathrm{mg}$ ( $0.415 \mathrm{mmol}, 0.5$ eq. $)$ of $\mathrm{MnCl}_{2}$ were dissolved in an acetonitrile-methanol mixture $(0.41 \mathrm{~mL}: 0.41 \mathrm{~mL})$. After complete dissolution of $\mathrm{MnCl}_{2}, 86.4 \mathrm{mg}$ (0.994 mmol; 1.2 eq.) of $\mathrm{MnO}_{2}$ were added. The reaction mixture was stirred at $40{ }^{\circ} \mathrm{C}$ and $505 \mu \mathrm{L}$ (3.98 mmol; 4.8 eq.) of TMSCl were added at once. The reaction mixture became black and was stirred at $40{ }^{\circ} \mathrm{C}$ for $19 \mathrm{~h}$ after which it was diluted with pentane $(20 \mathrm{~mL})$ and washed with an aqueous $\mathrm{NaOH}$ solution $(1.5 \% ; 2 \times 20 \mathrm{~mL})$. The aqueous phase was extracted with pentane $(2 \times 20 \mathrm{~mL})$. The combined organic phases were dried, evaporated in vacuo and the resulting residue was flash chromatographed on silica gel (hexane $/ \mathrm{CH}_{2} \mathrm{Cl}_{2}$ 7:3) to afford $196 \mathrm{mg}$ of a mixture of 2-chlorohexadecanal methyl acetal [25] (67\%) and methyl palmitate (12\%). IR: 2924, 2854, 1468, 1190, 1120, 1080, $722 \mathrm{~cm}^{-1}$. EIMS: $\mathrm{C}_{18} \mathrm{H}_{37} \mathrm{O}_{2} \mathrm{Cl}(\mathrm{M}=320,322) ; \mathrm{m} / \mathrm{z}=322\left(\mathrm{M}^{+\bullet}{ }^{37} \mathrm{Cl}, 0.3\right), 320$ $\left(\mathrm{M}^{+\bullet}{ }^{35} \mathrm{Cl}, 0.7\right.$ ), 321 (0.7), 319 (2.6), 75 (100). ${ }^{1} \mathrm{H}-\mathrm{NMR}$ : $4.31(\mathrm{~d}, 5.7 \mathrm{~Hz}, 1 \mathrm{H}) ; 3.87(\mathrm{~m}, 1 \mathrm{H}) ; 3.44(\mathrm{~s}, 6 \mathrm{H}) ; 1.65(\mathrm{~m}$, $4 \mathrm{H}) ; 1.26$ (m, $22 \mathrm{H}) ; 0.88$ (m, $3 \mathrm{H})$.

2-Chlorohexadecanal [7]. To $46.0 \mathrm{mg}(0.143 \mathrm{mmol})$ of 2-chlorohexadecanal methyl acetal [25] in $0.5 \mathrm{~mL}$ of $\mathrm{CH}_{2} \mathrm{Cl}_{2}$ were added $125 \mu \mathrm{L}$ of trifluoroacetic acid and 125 $\mu \mathrm{L}$ of water. The reaction mixture was stirred at reflux for $4 \mathrm{~h}$ after which it was diluted with $\mathrm{CH}_{2} \mathrm{Cl}_{2}(20 \mathrm{~mL})$ and washed with an aqueous $\mathrm{NaHCO}_{3}$ solution $(5 \% ; 3 \times 20 \mathrm{~mL})$. The aqueous phase was extracted with $\mathrm{CH}_{2} \mathrm{Cl}_{2}(3 \times 20 \mathrm{~mL})$ and the combined organic phases were dried, evaporated in vacuo and the resulting residue was flash chromatographed on silica gel (hexane/ $\mathrm{CH}_{2} \mathrm{Cl}_{2} 7: 3$ ) to afford $28 \mathrm{mg}(71 \%)$ of 2-chlorohexadecanal [7] as a solid. M.p.: 49-50 ${ }^{\circ} \mathrm{C}$. IR: 2924, 2854, 2714, 1738, 1466, $722 \mathrm{~cm}^{-1}$. EIMS: $\mathrm{C}_{16} \mathrm{H}_{31} \mathrm{OCl}$ $(\mathrm{M}=274,276) ; \mathrm{m} / \mathrm{z}=276\left(\mathrm{M}^{+\bullet}{ }^{37} \mathrm{Cl}, 3.6\right), 274\left(\mathrm{M}^{+\bullet}{ }^{35} \mathrm{Cl}\right.$, 7.9), 256 (2.1), 239 (1.4), 221 (8.6), 196 (14), 80 (14), 78 (41), 43 (100). ${ }^{1} \mathrm{H}-\mathrm{NMR}: 9.48$ (d, $2.5 \mathrm{~Hz}, 1 \mathrm{H}$ ); 4.15 (ddd, $8.1 \mathrm{~Hz}, 5.5 \mathrm{~Hz}, 2.5 \mathrm{~Hz}, 1 \mathrm{H}) ; 1.88(\mathrm{~m} ; 2 \mathrm{H}) ; 1.26$ (m, $24 \mathrm{H})$; 0.88 (m, $3 \mathrm{H})$.

2-Bromopalmitic acid methyl ester [27]. A mixture of

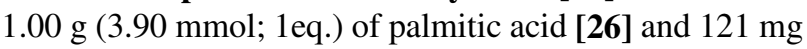
(3.90 mmol; 1eq.) of red phosphorus was heated at $80{ }^{\circ} \mathrm{C}$. After melting of the palmitic acid, $728 \mu \mathrm{L}(14.2 \mathrm{mmol} ; 3.6$ eq.) of bromine was added dropwise over $1 \mathrm{~h}$. The reaction mixture was stirred at $80{ }^{\circ} \mathrm{C}$ for $24 \mathrm{~h}$, after which it was cooled at $0{ }^{\circ} \mathrm{C}$ (ice bath) and $440 \mu \mathrm{L}$ of methanol were added dropwise over $1 \mathrm{~h}$. The reaction mixture was stirred at rt. for $30 \mathrm{~min}$. and heated at $80{ }^{\circ} \mathrm{C}$ for $1 \mathrm{~h}$. It was diluted under stirring with hexane $(25 \mathrm{~mL})$ and with an aqueous $\mathrm{NaHSO}_{3}$ solution $(50 \mathrm{~mL}, 1 \%)$. The aqueous phase was extracted with hexane $(25 \mathrm{~mL})$ and the combined organic phases were washed with water $(4 \times 25 \mathrm{~mL})$ until neutral $\mathrm{pH}$. The organic phase was dried, evaporated in vacuo and the resulting residue was flash chromatographed on silica gel (hexane/ $\mathrm{CH}_{2} \mathrm{Cl}_{2}$ 7:3) to afford $906 \mathrm{mg}$ (67\%) of 2-bromopalmitic acid methyl ester as an oil. IR: 2924, 2854, 1748, 1464, 1436, 1272, $1152 \mathrm{~cm}^{-1}$. EIMS: $\mathrm{C}_{17} \mathrm{H}_{33} \mathrm{O}_{2} \mathrm{Br}(\mathrm{M}$ $=348,350) ; \mathrm{m} / \mathrm{z}=350\left(\mathrm{M}^{+\bullet 81} \mathrm{Br}, 37\right), 348\left(\mathrm{M}^{+\bullet 79} \mathrm{Br}, 36\right)$, 
319 (2), 317 (1.5), 269 (100), 138 (100), 136 (100), 59 (83). ${ }^{1} \mathrm{H}-\mathrm{NMR}: 4.22$ (t, $\left.7.4 \mathrm{~Hz}, 1 \mathrm{H}\right) ; 3.78$ (s, $\left.3 \mathrm{H}\right) ; 2.00$ (m, $\left.2 \mathrm{H}\right)$; 1.26 (m, $24 \mathrm{H}) ; 0.88$ (m, $3 \mathrm{H})$.

2-Fluoropalmitic acid methyl ester [29]. To $107 \mathrm{mg}$ of 2-bromopalmitic acid methyl ester [27] (0.306 mmol; 1 eq.) dissolved in $704 \mu \mathrm{L}$ of acetonitrile were added $1.8 \mu \mathrm{L}$ of water and $176 \mathrm{mg}$ (1.38 mmol; 4.5 eq.) of $\mathrm{AgF}$. The reaction mixture was stirred at $80{ }^{\circ} \mathrm{C}$ for $48 \mathrm{~h}$ after which it was filtered with $\mathrm{CH}_{2} \mathrm{Cl}_{2}(10 \mathrm{~mL})$ on a short silica gel column. The organic phase was evaporated in vacuo and the resulting residue was flash chromatographed on silica gel (hexane/ $\mathrm{CH}_{2} \mathrm{Cl}_{2}$ 7:3) to afford $44.3 \mathrm{mg}(50 \%)$ of 2-fluoropalmitic acid methyl ester [29] as a white solid. M.p.: $34-35{ }^{\circ}$ C. IR: $2954,2925,2854,1770,1747,1467$, 1440, 1287, $1212 \mathrm{~cm}^{-1}$. EIMS: $\mathrm{C}_{17} \mathrm{H}_{33} \mathrm{O}_{2} \mathrm{~F}(\mathrm{M}=288) ; \mathrm{m} / \mathrm{z}$ : $288\left(\mathrm{M}^{+\bullet}, 69\right), 269$ (0.7), 227 (76), 161 (96), 147 (67), 105 (48), 92 (100), 59 (24). ${ }^{1} \mathrm{H}-\mathrm{NMR}: 4.90$ (dt, $48.9 \mathrm{~Hz}, 6.3 \mathrm{~Hz}$, $1 \mathrm{H}) ; 3.79(\mathrm{~s}, 3 \mathrm{H}) ; 1.88(\mathrm{~m}, 2 \mathrm{H}) ; 1.26(\mathrm{~m}, 24 \mathrm{H}) ; 0.88$ (m, $3 \mathrm{H})$.

2-Fluorohexadecanol. To a suspension of $11.8 \mathrm{mg}$ ( $0.312 \mathrm{mmol} ; 3$ eq.) of $\mathrm{LiAlH}_{4}$ in $2 \mathrm{~mL}$ of dry diethylether under stirring, were added dropwise $30.0 \mathrm{mg}(0.104 \mathrm{mmol}$; 1eq.) of 2-fluoropalmitic acid methyl ester [29] dissolved in $2 \mathrm{~mL}$ of dry diethylether. The reaction mixture was refluxed for $4 \mathrm{~h}$, after which it was quenched by addition of ethyl acetate $(1 \mathrm{~mL})$ and water $(1 \mathrm{~mL})$. The resulting mixture was stirred at rt. for $4 \mathrm{~h}$. Filtration on a short silica gel column (elution with $10 \mathrm{~mL}$ of diethylether) and evaporation of the solvent in vacuo afforded $22.6 \mathrm{mg}$ (83\%) of 2-fluorohexadecanol as a white solid. M.p.: $58-60{ }^{\circ} \mathrm{C}$. IR: $3269,2955,2916,2849,1470,1072 \mathrm{~cm}^{-1}$. EIMS: $\mathrm{C}_{16} \mathrm{H}_{33} \mathrm{OF}(\mathrm{M}=260) ; \mathrm{m} / \mathrm{z}=260\left(\mathrm{M}^{+\bullet},>0\right), 196(24), 113$ (26), 99 (44), 85 (100), 71 (100), 57 (100), 43 (100), 31 (85), 29 (100). ${ }^{1} \mathrm{H}-\mathrm{NMR}: 4.50(\mathrm{dm}, 48.3 \mathrm{~Hz}, 1 \mathrm{H}) ; 3.77(\mathrm{dm}$, $23 \mathrm{~Hz}, 2 \mathrm{H}) ; 1.87$ (t, $6.4 \mathrm{~Hz}, 1 \mathrm{H}) ; 1.64$ (m, $2 \mathrm{H}) ; 1.26$ (m, $24 \mathrm{H}), 0.88$ (m, $3 \mathrm{H})$.

2-Fluorohexadecanal [8]. 23.01 ( $0.251 \mathrm{mmol}$; 3.3 eq. $)$ of oxalyl chloride were dissolved in $200 \mu \mathrm{L}$ of dry $\mathrm{CH}_{2} \mathrm{Cl}_{2}$ and stirred at $-40{ }^{\circ} \mathrm{C}$ (dry ice-acetonitrile bath); $39 \mu \mathrm{L}$ ( $0.502 \mathrm{mmol} ; 6.6$ eq.) of DMSO were added over $2 \mathrm{~min}$; then, $19.8 \mathrm{mg}(0.0760 \mathrm{mmol} ; 1 \mathrm{eq}$.) of 2-fluorohexadecanol dissolved in $1 \mathrm{~mL}$ of $\mathrm{CH}_{2} \mathrm{Cl}_{2}$ were added dropwise over 5 min and the reaction mixture was stirred at $-40{ }^{\circ} \mathrm{C}$ for 15 $\min$. The reaction mixture was quenched by addition of 159 $\mu \mathrm{L}$ (1.14 mmol; 15 eq.) of triethylamine, stirred $5 \mathrm{~min}$ at $-40{ }^{\circ} \mathrm{C}$ and allowed to warm at $\mathrm{rt}$. It was diluted with $\mathrm{CH}_{2} \mathrm{Cl}_{2}$ $(10 \mathrm{~mL})$ and washed with water $(10 \mathrm{~mL})$. The aqueous phase was extracted with $\mathrm{CH}_{2} \mathrm{Cl}_{2}(2 \times 10 \mathrm{~mL})$. The combined organic phases were dried, evaporated in vacuo to afford $18.0 \mathrm{mg}(92 \%)$ of 2-fluorohexadecanal as a white solid. M.p.: 58-59 ${ }^{\circ}$ C. IR: 2916, 2848, 1736, $1468 \mathrm{~cm}^{-1}$. EIMS: $\mathrm{C}_{16} \mathrm{H}_{31} \mathrm{OF}(\mathrm{M}: 258) ; \mathrm{m} / \mathrm{z}=258\left(\mathrm{M}^{+\bullet}, 3\right), 239$ (3), 238 (7), 98 (100), 84 (59), 71 (21), 62 (5), 57 (44), 43 (49),
29 (14). ${ }^{1} \mathrm{H}-\mathrm{NMR}: 9.76$ (dd, $\left.6.2 \mathrm{~Hz}, 0.73 \mathrm{~Hz}, 1 \mathrm{H}\right) ; 4.81$ $(\mathrm{dm}, 48.8 \mathrm{~Hz}, 1 \mathrm{H}) ; 1.82(\mathrm{~m}, 2 \mathrm{H}) ; 1.46(\mathrm{~m}, 2 \mathrm{H}), 1.26$ (m, $22 \mathrm{H}), 0.88$ (m, $3 \mathrm{H})$.

1,2-Hexadecanediol [31]. To a solution of $1.00 \mathrm{~g} \mathrm{(4.46}$ mmol; 1 eq.) 1 -hexadecene [30] in $100 \mathrm{~mL}$ of acetone, were added $15.0 \mathrm{mg}(0.0579 \mathrm{mmol} ; 0.013 \mathrm{eq}$.) of osmium tertroxide and $90.0 \mathrm{mg}$ ( $6.68 \mathrm{mmol} ; 1.5 \mathrm{eq}$.) of $\mathrm{N}$-methylmorpholine monohydrate. The reaction mixture was stirred for $24 \mathrm{~h}$ at rt. It was then diluted with an aqueous sodium bisulfite solution $(10 \%, 100 \mathrm{~mL})$ and stirred for $45 \mathrm{~min}$. after which it was washed with $50 \mathrm{~mL}$ of brine and the aqueous phase was extracted with $\mathrm{CH}_{2} \mathrm{Cl}_{2}(4 \times 50 \mathrm{~mL})$. The organic extracts were dried and evaporated in vacuo and the resulting residue was flash chromatographed on silica gel (hexane/diethylether 7:3) affording $913 \mathrm{mg}$ of [31] (80\%) as a white solid. IR (solution, $\mathrm{CHCl}_{3}, 0.01 \mathrm{M}$ ): 3684,3626 , 3594, 3574, 3038, 3006, 2928, 2856, 1464, 1240, 1194, 1054, $928 \mathrm{~cm}^{-1}$. EIMS: $\mathrm{C}_{16} \mathrm{H}_{34} \mathrm{O}_{2}(\mathrm{M}=258) ; \mathrm{m} / \mathrm{z}=227$ (61), 83 (100), 69, 61 (35), 55, 43. ${ }^{1} \mathrm{H}-\mathrm{NMR}: 3.72$ (m, $\left.1 \mathrm{H}\right)$; 3.66 (dd, $10.8 \mathrm{~Hz}, 3.0 \mathrm{~Hz}, 1 \mathrm{H}) ; 3.43$ (dd, $10.8 \mathrm{~Hz}, 7.5 \mathrm{~Hz}$, 1H); 1.84 (bs, $2 \mathrm{H}) ; 1.26$ (m, $26 \mathrm{H}) ; 0.88$ (m, 3H).

1-Tert-butyldimethylsilyloxy-2-hydroxyhexadecane [32]. To a solution of $700 \mathrm{mg}$ ( $2.71 \mathrm{mmol} ; 1$ eq.) of 1,2-hexadecanediol [31] in $13 \mathrm{~mL}$ of $\mathrm{CH}_{2} \mathrm{Cl}_{2}$ were added $13.2 \mathrm{mg}$ (0.108 mmol; 0.04 eq.) of DMAP, $450 \mathrm{mg}$ (2.99 mmol; 1.1 eq.) of tert-butyldimethylsilyl chloride and 414 $\mu \mathrm{L}$ (2.99 mmol; 1.1 eq.) of triethylamine. The reaction mixture was stirred for $22 \mathrm{~h}$ after which it was diluted with $\mathrm{CH}_{2} \mathrm{Cl}_{2}(20 \mathrm{~mL})$, washed with water $(20 \mathrm{~mL})$ and with a saturated aqueous $\mathrm{NH}_{4} \mathrm{Cl}$ solution $(20 \mathrm{~mL})$. The combined organic phases were dried, concentrated in vacuo and the residue flash chromatographed on silica gel (hexane/diethylether 6:4) to afford $940 \mathrm{mg}$ of 1-tert-butyldimethylsilyloxy-2-hydroxyhexadecane [32] as an oil (93\%). IR: 3466, 2954, 2926, 2854, 1464, 1362, 1254, 1112, 1096, 1006, 838, $778 \mathrm{~cm}^{-1}$. EIMS: $\mathrm{C}_{22} \mathrm{H}_{48} \mathrm{O}_{2} \mathrm{Si}(\mathrm{M}=372) ; \mathrm{m} / \mathrm{z}=$ $341\left(\mathrm{M}^{+\bullet}-\mathrm{CH}_{3}-\mathrm{CH}_{3}-\mathrm{H}, 5\right), 315\left(\mathrm{M}^{+\bullet}-\mathrm{C}_{4} \mathrm{H}_{9}, 33\right), 297$ (21 ), $175\left(\mathrm{M}^{+\bullet}-\mathrm{C}_{14} \mathrm{H}_{29}, 6\right), 147$ (11), 131 (29), 115 (16), 105 (80), 75 (100). ${ }^{1}$ H-NMR: 3.61 (m, 1H); 3.61 (dd, 10.5 $\mathrm{Hz}, 3.2 \mathrm{~Hz}, 1 \mathrm{H}) ; 3.38$ (dd, $10.5 \mathrm{~Hz}, 8.3 \mathrm{~Hz}, 1 \mathrm{H}) ; 2.38$ (bs, 1H); 1.25 (m, $28 \mathrm{H}) ; 0.90$ (s, $9 \mathrm{H}) ; 0.87$ (m, 3H); 0.065 (s, $6 \mathrm{H})$.

1-Tert-butyldimethylsilyloxy-2-mesyloxyhexadecane [33]. To a solution of $940 \mathrm{mg}(2.52 \mathrm{mmol}$; 1 eq.) of 1-tertbutyldimethylsilyloxy-2-hydroxyhexadecane [32] and 526 $\mu \mathrm{L}$ (3.78 mmol; 1.5 eq.) of triethylamine in $13 \mathrm{~mL}$ of dry $\mathrm{CH}_{2} \mathrm{Cl}_{2}$ at $0{ }^{\circ} \mathrm{C}$, were added dropwise over $3 \min 215 \mu \mathrm{L}$ ( $2.78 \mathrm{mmol} ; 1.1$ eq.) of mesylchloride. The reaction mixture was stirred for $10 \mathrm{~min}$ at $0{ }^{\circ} \mathrm{C}, 80 \mathrm{~min}$. at rt. and then, diluted with brine $(10 \mathrm{~mL})$. The aqueous phase was extracted with $\mathrm{CH}_{2} \mathrm{Cl}_{2}(3 \times 10 \mathrm{~mL})$ and the combined organic phases were dried, concentrated in vacuo to afford pure 1-tert-butyldimethylsilyloxy-2-mesyloxyhexadecane [33] 
as an oil (1.02 g, 92\%). IR: 2954, 2926, 2856, 1464, 1360, 1254, 1178, 1118, 920, 838, $780 \mathrm{~cm}^{-1}$. EIMS: $\mathrm{C}_{23} \mathrm{H}_{50} \mathrm{O}_{4} \mathrm{SiS}$ $(\mathrm{M}=450) ; \mathrm{m} / \mathrm{z}=429$ (1.8), 355 (3.4), 341 (1.7), 298 (7), 297 (23), 195 (7), 171 (17), 153 (100), 75 (41), 73 (36). ${ }^{1} \mathrm{H}-\mathrm{NMR}: 4.64$ (m, $\left.1 \mathrm{H}\right) ; 3.74$ (d, $\left.2.5 \mathrm{~Hz}, 1 \mathrm{H}\right) ; 3.72$ (d, 0.9 $\mathrm{Hz}, 1 \mathrm{H}) ; 3.04$ (s, $3 \mathrm{H}) ; 1.65$ (m, $2 \mathrm{H}) ; 1.26$ (m, $24 \mathrm{H}) ; 0.90$ (s, $9 \mathrm{H}), 0.88$ (m, $3 \mathrm{H}), 0.082$ (s, $3 \mathrm{H}) ; 0.075$ (s, $3 \mathrm{H})$.

2-Mesyloxyhexadecanol [34]. To a solution of $77.3 \mathrm{mg}$ (0.190 mmol; 1 eq.) of 1-tert-butyldimethylsilyloxy-2mesyloxyhexadecane [33] in $2 \mathrm{~mL}$ of $\mathrm{CH}_{2} \mathrm{Cl}_{2}$ were added $0.9 \mathrm{~mL}$ trifluoroacetic acid and $0.1 \mathrm{~mL}$ of water. The reaction mixture was stirred vigorously for $67 \mathrm{~h}$ at rt., and then, diluted with $\mathrm{CH}_{2} \mathrm{Cl}_{2}(10 \mathrm{~mL})$ and neutralized with an aqueous $\mathrm{NaHCO}_{3}$ solution $(10 \%)$. The aqueous phase was extracted with $\mathrm{CH}_{2} \mathrm{Cl}_{2}(3 \times 20 \mathrm{~mL})$ and the combined organic phases were dried, concentrated in vacuo and the residue flash chromatographed on silica gel (hexane/diethylether 8:2) to afford 2-mesyloxyhexadecanol [34] as a white solid (49.3 mg, 77\%). M.p.: $50-51^{\circ} \mathrm{C}$. IR: 3532, 3034, 2956, 2918, 2852, 1470, 1328, 1164, 1072, 976, 920, 804, $720 \mathrm{~cm}^{-1}$. EIMS: $\mathrm{C}_{17} \mathrm{H}_{36} \mathrm{O}_{4} \mathrm{~S}(\mathrm{M}=336) ; \mathrm{m} / \mathrm{z}$ = 269 (0.7), 240 (2), 241 (4), 227 (37), 194 (12), 180 (6), 43 (100). ${ }^{1} \mathrm{H}-\mathrm{NMR}: 4.76(\mathrm{~m}, 1 \mathrm{H}) ; 3.81$ (dd, $12.5 \mathrm{~Hz}, 3.0$ $\mathrm{Hz}, 1 \mathrm{H}) ; 3.71$ (dd, $12.5 \mathrm{~Hz}, 6.8 \mathrm{~Hz}, 1 \mathrm{H}) ; 3.09$ (s, 3H); 1.50-1.74 (m, $2 \mathrm{H}) ; 1.26$ (m, $24 \mathrm{H}) ; 0.88$ (m, $3 \mathrm{H})$.

2-Mesyloxyhexadecanal [10]. It was synthesized following the same procedure as that described for the synthesis of 2-fluorohexadecanal (see above). Oil (yield: 58\%). IR: 3030, 2920, 2852, 1742, 1468, 1348, 1174, 1072, 1046, 972, 942, 920, $722 \mathrm{~cm}^{-1}$. EIMS: $\mathrm{C}_{17} \mathrm{H}_{34} \mathrm{O}_{4} \mathrm{~S}(\mathrm{M}=334) ; \mathrm{m} / \mathrm{z}$ = $334\left(\mathrm{M}^{+\bullet}, 0.24\right), 305$ (0.86), 291 (0.12), 278 (0.18), 209 (7), 138 (14), 55 (100). ${ }^{1} \mathrm{H}-\mathrm{NMR}: 9.54$ (d, $\left.0.7 \mathrm{~Hz}, 1 \mathrm{H}\right)$; 4.86 (ddd, $8.0 \mathrm{~Hz}, 4.7 \mathrm{~Hz}, 0.7 \mathrm{~Hz}, 1 \mathrm{H}) ; 3.08$ (s, $3 \mathrm{H})$; 1.66-1.89 (m, $2 \mathrm{H}) ; 1.18$ (m, $24 \mathrm{H}) ; 0.80$ (m, $3 \mathrm{H})$.

2-Heptadecanol [35]. To $152 \mathrm{mg}(6.24 \mathrm{mmol} ; 3 \mathrm{eq}$.$) of$ magnesium (Aldrich) suspended in $7 \mathrm{~mL}$ of dry diethylether at rt., were added dropwise $388 \mu \mathrm{L}(6.24$ mmol; 3 eq.) of methyl iodide dissolved in $7 \mathrm{~mL}$ of dry diethylether over $35 \mathrm{~min}$. To this mixture under stirring, were added dropwise over $15 \mathrm{~min} 500 \mathrm{mg}$ (2.08 mmol; 1 eq.) of $n$-hexadecanal dissolved in $7 \mathrm{~mL}$ of dry diethylether. After $45 \mathrm{~min}$, the reaction mixture was quenched by addition of water $(20 \mathrm{~mL})$ and of an aqueous $\mathrm{H}_{2} \mathrm{SO}_{4}$ solution $(15 \% ; 4 \mathrm{~mL})$ and diluted with diethylether $(10 \mathrm{~mL})$. After washing of the organic phase with water $(3 \times 15 \mathrm{~mL})$, drying and evaporation in vacuo, the residue was flash chromatographed on silica gel (hexane/diethylether 7:3) to afford 2-heptadecanol [35] as a solid (298 mg, 53\%). M.p.: 35-36 ${ }^{\circ} \mathrm{C}$. IR: 3345, 2956, 2916, 2849, $1467 \mathrm{~cm}^{-1}$. EIMS: $\mathrm{C}_{17} \mathrm{H}_{36} \mathrm{O}$ $(\mathrm{M}=256) ; \mathrm{m} / \mathrm{z}=256\left(\mathrm{M}^{+\bullet}, 2.2\right), 255$ (14), 241 (27), 238 (73), 210 (37), 99 (30), 85 (100), 71 (100), 57 (100), 43 (100), 29 (64). ${ }^{1} \mathrm{H}-\mathrm{NMR}: 3.77$ (m, $\left.1 \mathrm{H}\right) ; 1.42$ (m, $\left.2 \mathrm{H}\right) ; 1.26$ (m, $26 \mathrm{H}) ; 1.18$ (d, 6.1 Hz, $3 \mathrm{H}) ; 0.88$ (m, $3 \mathrm{H})$.
2-Heptadecanone [36]. $53.0 \mathrm{mg}(0.246 \mathrm{mmol}$; 1.5 eq.) of PCC (freshly recrystallised from water) were suspended in $600 \mu \mathrm{L}$ of dry $\mathrm{CH}_{2} \mathrm{Cl}_{2} ; 42.0 \mathrm{mg}(0.164 \mathrm{mmol} ; 1$ eq.) of 2-heptadecanol [35] dissolved in $250 \mu \mathrm{L}$ of dry $\mathrm{CH}_{2} \mathrm{Cl}_{2}$ were added at once and the reaction mixture was stirred under reflux for $4 \mathrm{~h}$. The reaction mixture was diluted with $3 \mathrm{~mL}$ of dry diethylether, filtered and the black precipitate washed with diethylether. Evaporation of the filtrate in vacuo and filtration of the residue on Florisil (elution with $50 \mathrm{~mL}$ diethylether) afforded $38.8 \mathrm{mg}$ of crude 2-heptadecanone which was further flash chromatographed on silica gel (hexane/diethylether 95:5) to afford $26.6 \mathrm{mg}$ (64\%) of 2-heptadecanone [36] as a solid and $2.0 \mathrm{mg}$ of the starting alcohol [35] (5\%). M.p.: 42-43 ${ }^{\circ}$ C. IR: 2955, 2916, 2849, 1712, 1472, $1463 \mathrm{~cm}^{-1}$. EIMS: $\mathrm{C}_{17} \mathrm{H}_{34} \mathrm{O}(\mathrm{M}=254) ; \mathrm{m} / \mathrm{z}=$ 254 (M+•, 99), 239 (25), 196 (50), 99 (13), 85 (100), 71 (100), 58 (100), 57 (100), 43 (100), 29 (63). ${ }^{1} \mathrm{H}-\mathrm{NMR}: 2.41$ (t, $7.4 \mathrm{~Hz}, 2 \mathrm{H}) ; 2.13$ (s, $3 \mathrm{H}) ; 1.58$ (m, $2 \mathrm{H}) ; 1.26$ (m, 24 $\mathrm{H}) ; 0.88$ (m, $3 \mathrm{H})$.

3-Iodo-2-heptadecanone [17]. To $42.0 \mathrm{mg}(0.165$ mmol; 1 eq.) of 2-heptadecanone [36] in solution in $330 \mu \mathrm{L}$ of $\mathrm{CH}_{2} \mathrm{Cl}_{2}$ were added $22.4 \mathrm{mg}(0.0826 \mathrm{mmol} ; 0.5$ eq. $)$ of $\mathrm{HgCl}_{2}$ and $41.9 \mathrm{mg}(0.165 \mathrm{mmol} ; 1$ eq. $)$ of iodine. The heterogeneous reaction mixture was stirred vigorously at rt. for $2 \mathrm{~h}$ after which it was filtered, the solid was washed with $10 \mathrm{~mL}$ of $\mathrm{CH}_{2} \mathrm{Cl}_{2}$ and the organic extracts washed successively with an aqueous sodium thiosulfate solution $(0.1 \mathrm{~N}$; $10 \mathrm{~mL}$ ) and an aqueous saturated KI solution $(10 \mathrm{~mL})$. The organic phase was dried, evaporated in vacuo and the resulting residue flash chromatographed on silica gel (hexane/ $\mathrm{CH}_{2} \mathrm{Cl}_{2}$ 8:2) affording $33.2 \mathrm{mg}$ of a mixture of 3-iodo2-heptadecanone [17] (46\%) and 1-iodo-2-heptadecanone (7\%). The two regioisomers were separated by HPLC (reversed phase LichroCart $\mathrm{C}_{18} 100 \mu \mathrm{m}$; elution with $\left.\mathrm{CH}_{3} \mathrm{CN}\right)$.M.p.: $33-34^{\circ} \mathrm{C}$. IR: 2953, 2923, 2853, 1713, 1464 $\mathrm{cm}^{-1}$. EIMS: $\mathrm{C}_{17} \mathrm{H}_{34} \mathrm{OI}(\mathrm{M}=380) ; \mathrm{m} / \mathrm{z}=380\left(\mathrm{M}^{+\bullet},>0\right)$, 253 (56), 184 (42), 99 (22), 85 (37), 71 (100), 69 (63), 57 (98), 43 (100), 29 (39); ${ }^{1} \mathrm{H}-\mathrm{NMR}: 4.44$ (t, $\left.7.5 \mathrm{~Hz}, 1 \mathrm{H}\right) ; 2.41$ (s, $3 \mathrm{H}) ; 1.92$ (m, $2 \mathrm{H}) ; 1.26$ (m, $24 \mathrm{H}) ; 0.88$ (m, $3 \mathrm{H})$.

2-Iodopalmitic acid [18]. $400 \mathrm{mg}$ (1.56 mmol; 1 eq.) of palmitic acid [26], $99.0 \mathrm{mg}(0.390 \mathrm{mmol} ; 0.25$ eq.) of iodine and $104 \mu \mathrm{L}$ ( $1.56 \mathrm{mmol}$; 1 eq.) of chlorosulfonic acid were dissolved in $1.60 \mathrm{~mL}$ of dry 1,2-dichloroethane. The reaction mixture was heated at $80^{\circ} \mathrm{C}$ for $2 \mathrm{~h}$, after which it was diluted with 1,2-dichloroethane $(3 \mathrm{~mL})$ and washed successively with water $(2 \times 5 \mathrm{~mL})$ and an aqueous $\mathrm{Na}_{2} \mathrm{~S}_{2} \mathrm{O}_{3}$ solution $(0.1 \mathrm{~N})$ until the color changed from pink to white. The organic phase was dried, evaporated in vacuo and the resulting residue flash chromatographed on silica gel (AcOEt $+0.1 \% \mathrm{CF}_{3} \mathrm{COOH}$ ) affording $366 \mathrm{mg}$ of a $75: 25$ mixture of 2-iodopalmitic acid [18] and palmitic acid [26]. The two products were separated by HPLC [LicroCart, $\mathrm{C}_{18}$ $(100 \mu \mathrm{m}), \lambda=200 \mathrm{~nm}, \mathrm{CH}_{3} \mathrm{CN} /$ water $9: 1+0.1 \%$ 
$\mathrm{CF}_{3} \mathrm{COOH}, 10 \mathrm{~mL} / \mathrm{min}: \mathrm{t}_{\mathrm{R} 1}=8.35 \mathrm{~min}$ (palmitic acid), $\mathrm{t}_{\mathrm{R} 2}$ $=9.29$ min (2-iodopalmitic acid)]; 2-iodopalmitic acid [18] was isolated as an oil. IR: 2920, 2850, 1696, 1464, 1416 $\mathrm{cm}^{-1}$. EIMS: $\mathrm{C}_{16} \mathrm{H}_{31} \mathrm{O}_{2} \mathrm{I}(\mathrm{M}=382) ; \mathrm{m} / \mathrm{z}=382\left(\mathrm{M}^{+\bullet}, 1.5\right)$, 381 (3), 255 (83), 237(46), 57 (100). ${ }^{1} \mathrm{H}-\mathrm{NMR}: 4.32$ (dd, $7.6 \mathrm{~Hz}, 7.6 \mathrm{~Hz}, 1 \mathrm{H}) ; 1.97$ (m, $2 \mathrm{H}) ; 1.26$ (m, $28 \mathrm{H}) ; 0.88$ (m, $3 \mathrm{H})$.

2-Iodooctanoic acid. The same procedure as the one described for the preparation of 2-iodopalmitic acid was used. Thus, $440 \mu \mathrm{L}(2.77 \mathrm{mmol})$ of octanoic acid afforded after purification of the crude product by flash chromatography (AcOEt to AcOEt/EtOH 5:5 + 0.1\% $\left.\mathrm{CF}_{3} \mathrm{COOH}\right) 248$ $\mathrm{mg}$ of a 86:14 mixture of 2-iodooctanoic acid and octanoic acid. The two products were separated by HPLC [LicroCart, $\mathrm{C}_{18}(100 \mu \mathrm{m}), \lambda=200 \mathrm{~nm}, \mathrm{CH}_{3} \mathrm{CN} /$ water $7: 3+0.1 \%$ $\mathrm{CF}_{3} \mathrm{COOH}, 10 \mathrm{~mL} / \mathrm{min}: \mathrm{t}_{\mathrm{R} 1}=2.40 \mathrm{~min}$ (octanoic acid), $\mathrm{t}_{\mathrm{R} 2}$ $=3.54 \mathrm{~min}$ (2-iodooctanoic acid)]; 2-iodooctanoic acid was isolated as an oil. IR: 2956, 2927, 2857, 1713, 1704, 1435, $1417 \mathrm{~cm}^{-1}$. EIMS: $\mathrm{C}_{8} \mathrm{H}_{15} \mathrm{O}_{2} \mathrm{I}(\mathrm{M}=270) ; \mathrm{m} / \mathrm{z}=270\left(\mathrm{M}^{+\bullet}\right.$, 9), 143 (27), 125 (56), 28 (100). ${ }^{1} \mathrm{H}-\mathrm{NMR}: 4.43$ (dd, $7.6 \mathrm{~Hz}$, $7.6 \mathrm{~Hz}, 1 \mathrm{H})$; 1.97 (m, $2 \mathrm{H})$; 1.29 (m, $8 \mathrm{H})$; 0.89 (m, $3 \mathrm{H})$.

\section{2-Iodopalmitate methyl ester [19]}

By iodination of palmitic acid and esterification with methanol. $200 \mathrm{mg}(0.780 \mathrm{mmol} ; 1$ eq. $)$ of palmitic acid and $49.0 \mathrm{mg}$ ( $0.195 \mathrm{mmol}$; 0.25 eq.) of iodine were dissolved in $780 \mu \mathrm{L}$ of 1,2-dichloroethane. The reaction mixture was heated at $80{ }^{\circ} \mathrm{C}$ and after $2 \mathrm{~h} 30,1 \mathrm{~mL}$ of methanol $(24.7$ mmol, 32 eq.) was added. After $3 \mathrm{~h}$, the reaction mixture was cooled, diluted with $\mathrm{CH}_{2} \mathrm{Cl}_{2}(3 \mathrm{~mL})$ and washed successively with water $(2 \times 5 \mathrm{~mL})$ and an aqueous $\mathrm{Na}_{2} \mathrm{~S}_{2} \mathrm{O}_{3}$ solution $(0.1 \mathrm{~N})$ until the color changed from pink to colorless. The organic phase was dried, evaporated in vacuo and the resulting residue flash chromatographed on silica gel (hexane/ $\mathrm{CH}_{2} \mathrm{Cl}_{2}$ 7:3) affording $58.3 \mathrm{mg}$ of 2-iodopalmitate methyl ester [19] and $6.8 \mathrm{mg}$ of palmitate methyl ester.

By substitution of the bromine of 2-bromopalmitate methyl ester by iodine. $102 \mathrm{mg}(0.291 \mathrm{mmol} ; 1 \mathrm{eq}$.$) of$ 2-bromopalmitate methyl ester [27] and $305 \mathrm{mg}$ (2.03 mmol; 7 eq.) of anhydrous $\mathrm{NaI}$ were dissolved in $1 \mathrm{~mL}$ of acetonitrile at $50{ }^{\circ} \mathrm{C}$. After $20 \mathrm{~h}$, the reaction mixture was diluted with water $(10 \mathrm{~mL})$ and $\mathrm{CH}_{2} \mathrm{Cl}_{2}(10 \mathrm{~mL})$. An aqueous sodium thiosulfate solution $(0.1 \mathrm{~N})$ was added until discoloration of the aqueous phase. The latter was extracted with $\mathrm{CH}_{2} \mathrm{Cl}_{2}(3 \times 10 \mathrm{~mL})$ and the combined organic phases were dried, evaporated in vacuo affording $108 \mathrm{mg}$ (93\%) of 2-iodopalmitate methyl ester [19] as an oil. IR: 2951, 2924, 2853, 1740, 1464, 1435, 1261, $1134 \mathrm{~cm}^{-1}$. EIMS: $\mathrm{C}_{17} \mathrm{H}_{33} \mathrm{O}_{2} \mathrm{I}(\mathrm{M}=396) ; \mathrm{m} / \mathrm{z}=396\left(\mathrm{M}^{+\bullet}, 2\right), 365$ (2), $269(74)$, 237 (26), 219 (20), 200 (4.4), 87 (67), 85 (19), 71 (36), 59 (20), 57 (77), 43 (100), 29 (33). ${ }^{1} \mathrm{H}-\mathrm{NMR}: 4.30$ (t, $7.6 \mathrm{~Hz}$, $1 \mathrm{H}) ; 3.75$ (s, $3 \mathrm{H}) ; 1.97$ (m, $2 \mathrm{H}) ; 1.26(\mathrm{~m}, 24 \mathrm{H}) ; 0.88$ (m, $3 \mathrm{H})$.
2-Iodooctanoate methyl ester. The same procedure as the one described for the preparation of 2-iodopalmitate methyl ester was used. Thus, $400 \mu \mathrm{L}(2.77 \mathrm{mmol})$ of octanoic acid afforded, after purification by flash chromatography (hexane/ $\mathrm{CH}_{2} \mathrm{Cl}_{2}$ 7:3) $210 \mathrm{mg}$ of 2-iodooctanoate methyl ester and $51.6 \mathrm{mg}$ of octanoate methyl ester as oils. IR: 2954, 2927, 2871, 2857, 1738, 1456, 1435, 1260, 1209, 1170, $1134 \mathrm{~cm}^{-1}$. EIMS: $\mathrm{C}_{9} \mathrm{H}_{17} \mathrm{O}_{2} \mathrm{I}(\mathrm{M}=284) ; \mathrm{m} / \mathrm{z}=284$ $\left(\mathrm{M}^{+\bullet}, 4\right), 253$ (4), 200 (5), 157 (78), 125 (99), 97 (99), 83 (99), 57 (11), 55 (100), 43 (46), 29 (30). ${ }^{1} \mathrm{H}-\mathrm{NMR}: 4.30$ (t, $7.6 \mathrm{~Hz}, 1 \mathrm{H}) ; 3.75$ (s, $3 \mathrm{H}) ; 1.97(\mathrm{~m}, 2 \mathrm{H}) ; 1.29$ (m, $8 \mathrm{H})$; $0.88(\mathrm{~m}, 3 \mathrm{H})$.

2-Iodooctanol [38]. To a stirred solution of $40.2 \mathrm{mg}$ ( $0.158 \mathrm{mmol}$; 1 eq.) of 2-iodooctanal [3] in $3 \mathrm{~mL}$ of methanol kept at rt., were added at once $4.50 \mathrm{mg}(0.119 \mathrm{mmol}$; 0.75 eq.) of $\mathrm{NaBH}_{4}$. After $75 \mathrm{~min}$, the reaction mixture was quenched with water $(10 \mathrm{~mL})$, diluted with $\mathrm{CH}_{2} \mathrm{Cl}_{2}(10 \mathrm{~mL})$ and the organic phase washed with water $(3 \times 10 \mathrm{~mL})$. The aqueous phase was extracted with $\mathrm{CH}_{2} \mathrm{Cl}_{2}(2 \times 20 \mathrm{~mL})$. The combined organic phases were dried, evaporated in vacuo and the resulting residue flash chromatographed on silica gel (hexane/ $\mathrm{CH}_{2} \mathrm{Cl}_{2}$ 5:5) affording $19.9 \mathrm{mg}$ (49\%) of 2-iodooctanol [38] as an oil. IR: 3354, 2956, 2927, 2870, 2856, $1463 \mathrm{~cm}^{-1}$. EIMS: $\mathrm{C}_{8} \mathrm{H}_{17} \mathrm{OI}(\mathrm{M}=256) ; \mathrm{m} / \mathrm{z}=256$ $\left(\mathrm{M}^{+\bullet}, 9\right), 255$ (18), 239 (15), 225 (96), 129 (21), 85 (57), 84 (44), 71 (79), 57 (100), 43 (100), 29 (79). ${ }^{1} \mathrm{H}-\mathrm{NMR}: 4.23$ $(\mathrm{m}, 1 \mathrm{H}) ; 3.73(\mathrm{~m}, 2 \mathrm{H}) ; 1.92(\mathrm{t}, 6.6 \mathrm{~Hz}, 1 \mathrm{H}) ; 1.80(\mathrm{~m}, 2$ $\mathrm{H}) ; 1.29(\mathrm{~m}, 8 \mathrm{H}) ; 0.89(\mathrm{~m}, 3 \mathrm{H})$.

2-Iodohexadecanol [20]. The procedure was identical to the one described for the preparation of 2-iodooctanol.

2-Bromohexadecanamide [28]. A solution of $573 \mathrm{mg}$ (1.64 mmol) of 2-bromopalmitate methyl ester [27] in a mixture of methanol/chloroform $(17 \mathrm{~mL} / 2 \mathrm{~mL})$ was saturated with ammonia at $0{ }^{\circ} \mathrm{C}$ in a sealed tube. After $7 \mathrm{~h}$, solvent and ammonia were evaporated and the residue flash chromatographed on silica gel (hexane/ $\mathrm{CH}_{2} \mathrm{Cl}_{2}$ 7:3) to afford $258 \mathrm{mg}$ (45\%) of 2-bromopalmitate methyl ester [27] and $233 \mathrm{mg}(42 \%)$ of 2-bromohexadecanamide [28] as a solid. M.p: $84-85{ }^{\circ}$ C. IR: 3365, 3185, 2918, 2846, 1662, 1652, $1463 \mathrm{~cm}^{-1}$. EIMS: $\mathrm{C}_{16} \mathrm{H}_{32} \mathrm{ONBr}(\mathrm{M}=333,335) ; \mathrm{m} / \mathrm{z}$ $=335\left(\mathrm{M}^{+\bullet}{ }^{81} \mathrm{Br}, 6\right), 333\left(\mathrm{M}^{+\bullet}{ }^{79} \mathrm{Br}, 6\right), 254$ (100), $139(90)$, 137 (90), 98 (28), 83 (20), 72 (80), 69 (30), 59 (41), 55 (42), 43 (54). ${ }^{1} \mathrm{H}-\mathrm{NMR}$ : 6.27 (bs, $1 \mathrm{H}$ ); 5.59 (bs, $1 \mathrm{H}$ ); 4.29 (dd, 8.1 Hz, $5.3 \mathrm{~Hz}, 1 \mathrm{H})$; 1.94-2.18 (m, $2 \mathrm{H}) ; 1.26-1.53$ (m, 24 $\mathrm{H}) ; 0.88$ (m, $3 \mathrm{H})$.

2-Iodohexadecanamide [22]. To a solution of $140 \mathrm{mg}$ (0.420 mmol; 1 eq.) of 2-bromohexadecanamide [28] in 1 $\mathrm{mL}$ of acetonitrile were added $441 \mathrm{mg}$ (2.94 mmol; 7 eq.) of anhydrous NaI. The reaction mixture was stirred for 19 $\mathrm{h}$ at $80^{\circ} \mathrm{C}$, and then, diluted with water $(10 \mathrm{~mL})$ and $\mathrm{CH}_{2} \mathrm{Cl}_{2}$ (10 mL). An aqueous sodium thiosulfate solution $(0.1 \mathrm{~N})$ was added until discoloration of the aqueous phase, which was extracted with $\mathrm{CH}_{2} \mathrm{Cl}_{2}(3 \times 10 \mathrm{~mL})$ and the combined 
organic phases were dried, concentrated in vacuo to afford $147 \mathrm{mg}(92 \%)$ of 2-iodohexadecanamide [22]. M.p.: 105$107^{\circ}$ C. IR: $3366,3176,2916,2870,1650,1464,1426 \mathrm{~cm}^{-1}$. EIMS: $\mathrm{C}_{16} \mathrm{H}_{32} \mathrm{ONI}(\mathrm{M}=381) ; \mathrm{m} / \mathrm{z}=381\left(\mathrm{M}^{+\bullet}, 2\right), 254$ (100), 185 (11), 83 (18), 72 (70), 69 (26), 59 (74), 55 (38), 43 (56). ${ }^{1} \mathrm{H}-\mathrm{NMR}$ : 6.77 (bs, $\left.1 \mathrm{H}\right) ; 5.40(\mathrm{bs} ; 1 \mathrm{H}) ; 4.26(\mathrm{t}$, $7.4 \mathrm{~Hz}, 1 \mathrm{H}) ; 1.94-2.03$ (m, $2 \mathrm{H}) ; 1.26-1.53$ (m, $24 \mathrm{H}) ; 0.88$ $(\mathrm{m}, 3 \mathrm{H})$.

2-Hydroxyhexadecanenitrile [42]. To a solution of $700 \mathrm{mg}$ (3.09 mmol; 1 eq.) of $n$-pentadecanal [40] in $17 \mathrm{~mL}$ of $\mathrm{CH}_{2} \mathrm{Cl}_{2}$ were added $618 \mu \mathrm{L}$ (4.64 mmol; 1.5 eq.) of trimethylsilyl cyanide and $3.0 \mathrm{mg}(0.00940 \mathrm{mmol} ; 0.003$ eq.) of $\mathrm{ZnI}$. After stirring for $5 \mathrm{~h}$ at rt., the 2-trimethylsilyloxyhexadecanenitrile [41] was hydrolyzed by addition of a citric acid solution in methanol $(10 \% ; 20 \mathrm{~mL})$ at $\mathrm{rt}$. After $18 \mathrm{~h}$, the reaction mixture was diluted with water $(20 \mathrm{~mL})$ and the aqueous phase was extracted with $\mathrm{CH}_{2} \mathrm{Cl}_{2}(3 \times 20$ $\mathrm{mL}$ ). The combined organic phases were washed with brine, dried, concentrated in vacuo and the residue flash chromatographed on silica gel (hexane/ $\mathrm{CH}_{2} \mathrm{Cl}_{2}$ 9:1 to $\mathrm{CH}_{2} \mathrm{Cl}_{2}$, then diethylether) to afford $23.0 \mathrm{mg}$ of starting n-pentadecanal (3\%) and $431 \mathrm{mg}(55 \%)$ of cyanohydrin 42 as a solid. M.p.: $39-40{ }^{\circ}$ C. IR: 3400, 2956, 2920, 2850, 2248, 1468, $1078 \mathrm{~cm}^{-1}$. EIMS: $\mathrm{C}_{16} \mathrm{H}_{31} \mathrm{NO}(\mathrm{M}=253) ; \mathrm{m} / \mathrm{z}$ $=253\left(\mathrm{M}^{+\bullet}, 5\right), 208$ (15), 182 (16) (100). ${ }^{1} \mathrm{H}-\mathrm{NMR}: 4.46$ (m, $1 \mathrm{H}) ; 2.96$ (bd; $5.6 \mathrm{~Hz}, 1 \mathrm{H}) ; 1.84(\mathrm{~m}, 2 \mathrm{H}) ; 1.26$ (m, 24 $\mathrm{H}) ; 0.88$ (m, $3 \mathrm{H})$.

2-Mesyloxyhexadecanitrile [43]. To a solution of 431 mg (2.55 mmol; 1 eq.) of cyanohydrin [42] and $355 \mu \mathrm{L}$ (2.55 mmol; 1.5 eq.) of triethylamine in $8.5 \mathrm{~mL}$ of dry $\mathrm{CH}_{2} \mathrm{Cl}_{2}$ at $0{ }^{\circ} \mathrm{C}$, were added dropwise over $3 \mathrm{~min} .145 \mu \mathrm{L}$ ( $1.87 \mathrm{mmol}$; 1.1 eq.) of mesylchloride. The reaction mixture was stirred for $10 \mathrm{~min}$. at $0{ }^{\circ} \mathrm{C}, 20 \mathrm{~min}$ at rt. after which it was diluted with brine $(10 \mathrm{~mL})$. The aqueous phase was extracted with $\mathrm{CH}_{2} \mathrm{Cl}_{2}(3 \mathrm{x} 10 \mathrm{~mL})$ and the combined organic phases were dried and concentrated in vacuo to afford $566 \mathrm{mg}(100 \%)$ of 2-mesyloxyhexadecanitrile [43] as a solid. M.p.: 59-61 ${ }^{\circ}$ C. IR: 2958, 2916, 2848, 1470, 1368, 1182, 964-818 cm $\mathrm{cm}^{-1}$. EIMS: $\mathrm{C}_{17} \mathrm{H}_{33} \mathrm{NO}_{3} \mathrm{~S}(\mathrm{M}=253)$; $\mathrm{m} / \mathrm{z}=331\left(\mathrm{M}^{+\bullet},>0\right), 252$ (97), 43 (100). ${ }^{1} \mathrm{H}-\mathrm{NMR}: 5.17$ (dd, 6.7 Hz, 6.7 Hz, $1 \mathrm{H}) ; 3.18$ (s, $3 \mathrm{H}) ; 2.00$ (m, $2 \mathrm{H}) ; 1.26$ (m, $24 \mathrm{H}) ; 0.88$ (m, $3 \mathrm{H})$.

2-Iodohexadecanenitrile [23]. $85.0 \mathrm{mg}(0.256 \mathrm{mmol}$; 1 eq.) of 2-mesyloxyhexadecanenitrile [43] and $270 \mathrm{mg}$ ( $1.79 \mathrm{mmol} ; 7$ eq.) of anhydrous $\mathrm{NaI}$ were dissolved in 2 $\mathrm{mL}$ of acetonitrile at $80^{\circ} \mathrm{C}$. After $4 \mathrm{~h}$, the reaction mixture was diluted with water $(10 \mathrm{~mL})$ and $\mathrm{CH}_{2} \mathrm{Cl}_{2}(10 \mathrm{~mL})$. An aqueous sodium thiosulfate solution $(0.1 \mathrm{~N})$ was added until discoloration of the aqueous phase which was extracted with $\mathrm{CH}_{2} \mathrm{Cl}_{2}(3 \times 10 \mathrm{~mL})$ and the combined organic phases were dried, concentrated in vacuo and the residue flash chromatographed on silica gel (hexane/ $\mathrm{CH}_{2} \mathrm{Cl}_{2}$ 9:1) to afford $43.0 \mathrm{mg}(57 \%)$ of 2-iodohexadecanenitrile [23] as an oil. IR: 2924, 2854, 2236, $1466 \mathrm{~cm}^{-1}$. EIMS: $\mathrm{C}_{16} \mathrm{H}_{30} \mathrm{NI}$ $(\mathrm{M}=363) ; \mathrm{m} / \mathrm{z}=363\left(\mathrm{M}^{+\bullet}, 2\right), 236$ (100), 192 (55), 128 (47), 124 (39), 110 (51), 97 (83), 43 (81). ${ }^{1} \mathrm{H}-\mathrm{NMR}: 4.20$ (dd, 7.1 Hz, 7.1 Hz, 1 H); 1.96-2.05 (m, $2 \mathrm{H}) ; 1.26$ (m, 24 $\mathrm{H}) ; 0.88$ (m, $3 \mathrm{H})$.

2-Bromo-2-nonanone [12]. To a solution of $855 \mu \mathrm{L}$ (5.00 mmol; 1 eq.) of 2-nonanone [15] in $10 \mathrm{~mL}$ of acetonitrile, were added dropwise and successively $726 \mu \mathrm{L}(5.50$ mmol; 1.1 eq.) of TMSBr and $390 \mu \mathrm{L}$ (5.50 mmol; 1 eq.) of DMSO. The reaction mixture was stirred for $40 \mathrm{~min}$. at rt. after which it was poured into water $(50 \mathrm{~mL})$. The aqueous phase was extracted with diethylether $(3 \times 20 \mathrm{~mL})$ and the combined organic phases were dried, concentrated in vacuo and the residue flash chromatographed on silica gel (hexane/ $\mathrm{CH}_{2} \mathrm{Cl}_{2}$ 9:1) to afford $712 \mathrm{mg}$ (64\%) of 3bromo-2-nonanone [12] as an oil. IR: 2958, 2928, 2858, 1720, 1462, 1428, 1358, 1228, 1172, 1148, $724 \mathrm{~cm}^{-1}$. EIMS: $\mathrm{C}_{9} \mathrm{H}_{17} \mathrm{OBr}\left(\mathrm{M}=220,222 ;{ }^{79} \mathrm{Br},{ }^{81} \mathrm{Br}\right) ; \mathrm{m} / \mathrm{z}=222$ $\left({ }^{81} \mathrm{M}^{+\bullet}, 0.04\right), 220\left({ }^{79} \mathrm{M}^{+\bullet}, 0.05\right), 193(0.02), 191(0.03), 180$ (0.04), 178 (0.04), 151 (0.05), 141 (1), 138 (8), 136 (9), 71 (5), 55 (9), 43 (100), 41 (20), 39 (10). ${ }^{1} \mathrm{H}-\mathrm{NMR}: 4.22$ (dd, $7.9 \mathrm{~Hz}, 6.7 \mathrm{~Hz}, 1 \mathrm{H}) ; 2.35$ (s, $3 \mathrm{H}) ; 1.96$ (m, $2 \mathrm{H}) ; 1.29$ (m, $8 \mathrm{H}) ; 0.89$ (m, $3 \mathrm{H})$.

3-Iodo-2-nonanone [11]. $50.5 \mathrm{mg}(0.228 \mathrm{mmol}$; 1eq.) of 3-bromo-2-nonanone [12] and $205 \mathrm{mg}$ (1.37 mmol; 6 eq.) of anhydrous $\mathrm{NaI}$ were dissolved in $2 \mathrm{~mL}$ of acetonitrile at $\mathrm{rt}$. After $3 \mathrm{~h}$, the reaction mixture was diluted with water (10 $\mathrm{mL})$ and $\mathrm{CH}_{2} \mathrm{Cl}_{2}(10 \mathrm{~mL})$. The organic phase was washed with water $(3 \times 10 \mathrm{~mL})$, dried and concentrated in vacuo to afford $47.2 \mathrm{mg}(77 \%)$ of pure 3-iodo-2-nonanone [11] as an oil. IR: 2956, 2926, 2856, 1712, 1462, 1432, 1358, 1126, 1200, 1166, 1130, 954, $722 \mathrm{~cm}^{-1}$. EIMS: $\mathrm{C}_{9} \mathrm{H}_{17} \mathrm{OI}(\mathrm{M}=268) ; \mathrm{m} / \mathrm{z}=184$ (0.2), 141 (0.4), 58 (47), 57 (29), 49 (93), 43 (100). ${ }^{1} \mathrm{H}-\mathrm{NMR}: 4.43$ (t, $7.5 \mathrm{~Hz}$, $1 \mathrm{H}) ; 2.41$ (s, $3 \mathrm{H}) ; 1.92(\mathrm{~m}, 2 \mathrm{H}) ; 1.28$ (m, $8 \mathrm{H}) ; 0.88$ (m; $3 \mathrm{H})$.

3-Chloro-2-nonanone [13]. $956 \mathrm{mg}$ (11.0 mmol; 1.1 eq.) of $\mathrm{MnO}_{2}$ were suspended in $20 \mathrm{~mL}$ of acetic acid in the presence of $1.71 \mathrm{~mL}$ (10.0 mmol; 1 eq.) of 2-nonanone [15]; $5.33 \mathrm{~mL}$ (42.0 mmol; 4.2 eq.) of TMSCl were added at once. The reaction mixture was stirred at $\mathrm{rt}$. for $16 \mathrm{~h}$ after which it was poured into water $(160 \mathrm{~mL})$ and extracted with diethylether $(3 \times 20 \mathrm{~mL})$. The combined organic extracts were neutralized with an aqueous $\mathrm{NaOH}$ solution $(0.025 \mathrm{M}$; $2 \times 80 \mathrm{~mL}$ ), dried, concentrated in vacuo and the residue flash chromatographed on silica gel (hexane/ $\mathrm{CH}_{2} \mathrm{Cl}_{2}$ 9: 1) to afford $162 \mathrm{mg}$ (92\%) of 3-chloro-2-nonanone [13] as an oil. IR: 2958, 2930, 2860, 1724, 1464, 1430, 1358, 1232, 1162, $1116 \mathrm{~cm}^{-1}$. EIMS: $\mathrm{C}_{9} \mathrm{H}_{17} \mathrm{OCl}\left(\mathrm{M}=176,178 ;{ }^{35} \mathrm{Cl}\right.$, $\left.{ }^{37} \mathrm{Cl}\right) ; \mathrm{m} / \mathrm{z}=178\left({ }^{37} \mathrm{M}^{+\bullet}, 0.15\right), 176\left({ }^{35} \mathrm{M}^{+\bullet}, 0.5\right), 147(0.4)$, 141 (0.1), 94 (9), 92 (24), 86 (31), 84 (42), 58 (20), 51 (25), 49 (50), 43 (100). ${ }^{1} \mathrm{H}-\mathrm{NMR}: 4.17$ (dd, $\left.8.3 \mathrm{~Hz}, 5.8 \mathrm{~Hz}, 1 \mathrm{H}\right)$; 
$2.31(\mathrm{~s}, 3 \mathrm{H}) ; 1.75-2.00(\mathrm{~m}, 2 \mathrm{H}) ; 1.29$ (m, $8 \mathrm{H}), 0.89$ (m, 3 $\mathrm{H})$.

3-Fluoro-2-nonanone [14]. To a solution of $122 \mathrm{mg}$ (0.550 mmol; 1 eq.) of 3-bromo-2-nonanone [12] in 2.75 $\mathrm{mL}$ of acetonitrile were added $1.4 \mu \mathrm{L}$ of water $(0.1 \%$ in weight of $\mathrm{AgF})$ and $140 \mathrm{mg}(1.10 \mathrm{mmol} ; 2$ eq. $)$ of $\mathrm{AgF}$. The reaction mixture was stirred at $80{ }^{\circ} \mathrm{C}$ for $24 \mathrm{~h}$ after which it was filtered on a short column of silica gel (elution with $20 \mathrm{~mL} \mathrm{CH}_{2} \mathrm{Cl}_{2}$ ). The filtrate was concentrated in vacuo and the residue flash chromatographed on silica gel (hexane/ $\mathrm{CH}_{2} \mathrm{Cl}_{2}$ 9:1). Evaporation of the solvent under nitrogen afforded 3-fluoro-2-nonanone [14] as an oil. IR: 2956, 2930, 2860, 1728, 1464, 1424, 1358, 1170, 1122, 1078 $\mathrm{cm}^{-1}$. EIMS: $\mathrm{C}_{9} \mathrm{H}_{17} \mathrm{OF}(\mathrm{M}=160) ; \mathrm{m} / \mathrm{z}=160\left(\mathrm{M}^{+\bullet}, 0.06\right)$, 72 (25), 76 (0.5), 43 (100). ${ }^{1} \mathrm{H}-\mathrm{NMR}: 4.71$ (dm, $50.6 \mathrm{~Hz}, 1$ $\mathrm{H}) ; 2.24(\mathrm{~d}, 4.7 \mathrm{~Hz}, 3 \mathrm{H}) ; 1.69-1.89$ (m, $2 \mathrm{H}) ; 1.29$ (m, 8 $\mathrm{H}) ; 0.88$ (m, $3 \mathrm{H})$.

3-Tosyloxy-2-nonanone [16] and 1-tosyloxy-2nonanone. To $600 \mu \mathrm{L}$ ( $3.52 \mathrm{mmol}$; 1 eq.) of 2-nonanone in $18 \mathrm{~mL}$ of dry acetonitrile was added $1.44 \mathrm{~g} \mathrm{(3.52 \textrm {mmol } ; 1}$ eq.) of HTIB. The reaction mixture was refluxed for $10 \mathrm{~min}$ after which the solvent was evaporated in vacuo. The crude residue was dissolved in pentane $(20 \mathrm{~mL})$ and the solution washed with water $(2 \times 10 \mathrm{~mL})$, dried and evaporated in vасио. The residue was flash chromatographed on silica gel (hexane/diethylether 8:2) to afford $333 \mathrm{mg}$ of 3-tosyloxy2-nonanone [16] (30\%) and $162 \mathrm{mg}$ of 1-tosyloxy-2nonanone $(15 \%)(67: 33)$ as oils.

3-Tosyloxy-2-nonanone [16]. IR: 2956, 2930, 2860, 1724, 1598, 1462, 1368, 1178, 1096, 952, 888, 832, 816, $772,668,556 \mathrm{~cm}^{-1}$. EIMS: $\mathrm{C}_{16} \mathrm{H}_{24} \mathrm{O}_{4} \mathrm{~S}(\mathrm{M}=312) ; \mathrm{m} / \mathrm{z}=$ $313\left(\mathrm{M}^{+\bullet}+\mathrm{H}, 0.5\right.$ ), 281 (1), 269 (21), 155 (100), 97 (25), 91 (100), 65 (22), 57 (14), 43 (42). ${ }^{1} \mathrm{H}-\mathrm{NMR}: 7.80$ (AA'XX' system, $2 \mathrm{H}$ ); 7.36 (AA'XX' system, $2 \mathrm{H}$ ); 4.59 (dd, $7.9 \mathrm{~Hz}, 4.9 \mathrm{~Hz}, 1 \mathrm{H}) ; 2.46(\mathrm{~s}, 3 \mathrm{H}) ; 2.20(\mathrm{~s}, 3 \mathrm{H})$; 1.61-1.70 (m, $2 \mathrm{H})$; 1.15 (m, $8 \mathrm{H})$; 0.84 (m, $3 \mathrm{H})$.

1-Tosyloxy-2-nonanone. IR: 2954, 2928, 2858, 1740, 1598, 1460, 1368, 1178, 1096, 1004, 818, 774, 668, 556 $\mathrm{cm}^{-1}$. EIMS: $\mathrm{C}_{16} \mathrm{H}_{24} \mathrm{O}_{4} \mathrm{~S}(\mathrm{M}=312) ; \mathrm{m} / \mathrm{z}=312\left(\mathrm{M}^{+\bullet}, 0.4\right)$, 282 (4), 228 (5), 127 (100), 91 (50), 65 (20), 57 (75), 43 (35). ${ }^{1} \mathrm{H}$-NMR: 7.82 (AA'XX' system, $2 \mathrm{H}$ ); 7.36 (AA'XX' system, $2 \mathrm{H}) ; 4.49$ (s, $2 \mathrm{H}) ; 2.48$ (t; $7.3 \mathrm{~Hz}, 2 \mathrm{H}$ ); 2.46 (s, 3 $\mathrm{H}) ; 1.52$ (m, $2 \mathrm{H}) ; 1.25$ (m, $8 \mathrm{H}) ; 0.88$ (m, $3 \mathrm{H})$.

\section{Acknowledgements}

One of us (H. V.d.B.) gratefully acknowledges the "Institut pour l'Encouragement de la Recherche Scientifique dans l'Industrie et l'Agriculture", the "Fonds pour la formation à la Recherche dans l'Industrie et dans l'Agriculture" and the "Fondation Van Buuren" for financial support. We thank Dr R. Ottinger for the NMR spectra and Dr M. Kaisin and Mr. C. Moulard for the mass spectra.

\section{References}

1.Pereira, A.; Braekman, J.Cl.; Dumont, J.E.; Boeynaems, J.M. J.Biol.Chem. 1990, 265, 17018.

2.Panneels, V.; Macours, P.; Van den Bergen, H.; Braekman, J.C.; Van Sande, J.; Boeynaems, J.M. J.Biol.Chem. 1996, 271, 23006.

3. Panneels, V.; Van den Bergen, H.; Jacoby, C.; Braekman, J.C.; Van Sande, J.; Dumont, J.E.; Boeynaems, J.M. Mol.Cell. Endocrinol. 1994, 102,167.

4. Panneels, V.; Van den Bergen, H.; Jacoby, C.; Braekman, J.C.; Van Sande, J.; Dumont, J.E.; Boeynaems, J.M. Mol.Cell. Endocrinol. 1994, 106, 41.

5. Jacoby, C.; Braekman, J.C.; Daloze, D. Tetrahedron 1996, 52, 10473.

6. Barluenga, J.; Martinez-Gallo, J.M.; Najera, C.;Yus M. Synthesis 1986, 678.

7. Armani, E.; Dossena, A.; Marchelli, R.; Castani, G. Tetrahedron, 1984, 40, 2035.

8. Corey, E.J.; Suggs, J.W. Tetrahedron Lett. 1975, 31, 2647.

9. Bellesia, F.; Boni, M.; Ghelfi, F.; Grandi, R.; Pagnoni, U.M.; Pinetti, A. Tetrahedron Lett., 1992, 48, 4579.

10. Boni, M.; Ghelfi, F.; Pagnoni, U.M.; Pinetti, A. Synth. Commun. 1993, 23, 1915.

11. Benincasa, M.; Boni, M.; Ghelfi, F.; Pagnoni, U.M. Synth. Commun. 1995, 25, 1843.

12. Stevens, C.L.; Farbas, E.; Gillis, B. J. Am. Chem. Soc. 1954, 76, 2695.

13. Reuss, R.H.; Hassner, A. J.Org.Chem. 1974, 39, 1785.

14. Fry, A.J.; Migron, Y. Tetrahedron Lett. 1979, 36, 3357.

15. Purrington, S.; Lazaridis, N.; Bumgardner C. Tetrahedron Lett. 1986, 27, 2715.

16. Timothy, B.P.; Hosseini, S.; Bains, S. Tetrahedron Lett. 1990, 31, 179.

17. Suga, H.; Schlosser, M. Tetrahedron 1990, 46, 4261.

18. De Kimpe, N.; Verhé, R. In The Chemistry of $\alpha$-haloketones, $\alpha$-haloaldehydes and $\alpha$-haloimines, Patai, S.; Rappoport, Z., eds., John Wiley Sons, Chichester, 1988.

19. Pogany, S.A.; Zentner, G.M.; Ringeisen, C.D. Synthesis 1987, 718.

20. Mancuso, A.J.; Huang, S-L.; Swern, D. J. Org. Chem. 1978, 43, 2480.

21. Ogata, Y.; Watanabe, S. J.Org.Chem. 1980, 45, 2831.

22. Granet, R.; Pierkarski, S.; C. R. Acad. Sc. Paris 1974, t279, serie C, 205.

23. Lodaya, J.S.; Koser, G.F. J.Org.Chem. 1988, 53, 210.

24. Koser, G.F.; Reelenyi, A.G.; Kalos, A.N.; Rebrovic, L.; Wettach, R.H. J.Org.Chem. 1982, 47, 2487.

25. Koser, G.F.; Reelenyi, A.G.; Kalos, A.N.; Rebrovic, L.; Wettach, R.H. J.Org.Chem. 1982, 47, 2487. 
26. Ogura, K.; Tsurada, T.; Takahashi, K.; Iiida, H. Tetrahedron Lett. 1986, 27, 3665.

27. a) Kirrmann, A.; Druesne, F. C. R. Acad. Sc. Paris 1964, 259, 3285; b) Huet, F.; Lechevalier, A.; Pellet, M.; Conia, J.M. Synthesis, 1978, 63; d) Yung, M.E.; Andrus, W.A.; Ornstein, P.L.; Tetrahedron Lett. 1977, $48,4175$.

28. Jacobsen, E.N.; Mark, I.; France, M.B.; Svendsen, J.S.; Sharpless, K.B. J. Am. Chem. Soc. 1989, 111, 737.

29. Chaudhary, S.K.; Hernandez, O. Tetrahedron Lett. 1979, 2, 99.

30. Crossland, R.K.; Servis, K.L. J.Org.Chem. 1970, 35 , 3195.

31. Baker, R.; Cummings, W.J.; Hayes, J.F.; Kumar, A. J. Chem. Soc., Chem. Commun. 1986, 1237.
32. Bellesia, F.; Ghelfi, F.; Grandi, R.; Pagnoni, U.M. J. Chem. Res. (S) 1986, 428.

33. Bellesia, F.; Ghelfi, F.; Pagnoni, U.M.; Pinetti, A. J. Chem. Res. (S) 1990, 188.

34. Bellesia, F.; Ghelfi, F.; Grandi, R.; Pagnoni, U.M. J. Chem. Res. (S) 1986, 426.

35. Evans, D.A.; Truesdale, L.K.; Carroll, G.L. J. Chem. Soc., Chem. Commun. 1973, 55.

36. Gassman, G.; Talley, J.J. Tetrahedron Lett. 1978, 40, 3773.

37. Reetz, M.T.; Drews, M.W.; Harms, K.; Reif, W. Tetrahedron Lett. 1988, 29, 3295.

38. Golinski, M.; Brock, C.P.; Watt, D.S. J.Org.Chem. 1993, 58, 159. 